\title{
EXPRESSIÓ D’UNA UDP-GLUCOSA: ESTEROL GLUCOSIL-TRANSFERASA DE TOMÀQUET A ESCHERICHIA COLI
}

\author{
Muro Blanc, ElenA ${ }^{1}$ \\ Departament de Bioquímica i Fisiologia \\ Facultat de Farmàcia i Ciències de l'Alimentació - UB \\ Av. Joan XIII, s/n, 08028 Barcelona
}

\begin{abstract}
Phytosterols can be found free (FS) or conjugated as steryl esters (SEs), steryl glucosides (SGs), or acylated steryl glucosides (ASGs). The content of conjugated sterols may vary greatly between species, tissues, and growing conditions. SG are primarily located in the plasma membrane, but their function is not yet fully known; they seem to play an important role in the regulation of the biophysical properties of the plasma membrane. The synthesis of SG is catalysed by UDP-glucose: sterol-glucosyltransferases (SGT). Studies suggest that plants contain multigenic families that codify SGT isoenzymes with specialised functions. In this study a system for the expression of isozyme SISGT1 in Eschericha coli has been developed, so that the recombinant enzyme can be subsequently purified, and its enzymatic activity characterised.
\end{abstract}

Keywords: sterol, gateway, plasmid, recombinant protein.

\section{Resumen}

Los fitoesteroles se pueden encontrar libres (FS) o conjugados, en forma de ésteres de esterol (SE), glucósidos de esterol (SG) o acilglucósidos de esterol (ASG). El contenido de esteroles conjugados varía entre especies, Tejidos y condiciones de crecimiento. Los SG forman parte de las membranas celulares. Su función todavía no se conoce por completo, se piensa que participan en la regulación de las propiedades de las membranas. La síntesis de SG está catalizada por las UDP-glucosa: esterol-glucosiltransferasas (SGT). Los estudios sugieren que las plantas contienen familias multigénicas que codifican isoenzimas SGT con funciones especializadas. En este trabajo se pone a punto un sistema de expresión del enzima SISGT1 en Escherichia coli, para poder posteriormente proceder a su purificación y a la caracterización bioquímica de su actividad enzimática de glucosilación frente a diferentes sustratos.

Palabras clave: esterol, Gateway, plásmido, proteína recombinante.

\section{Resum}

Els fitoesterols es poden trobar lliures (FS) o conjugats, en forma d'èsters d'esterols (SE), glucòsids d'esterols (SG) o acilglucòsids d'esterols (ASG). El contingut d'esterols conjugats varia entre espècies, teixits i condicions de creixement. Els SG formen part de les membranes cellulars. La seva funció no es coneix completament, però es pensa que participen en la regulació de les propietats de les membranes. La síntesi de SG està catalitzada per les UDP-glucoses: esterol-glucosil-ransferases (SGT). Els estudis suggereixen que les plantes contenen famílies multigèniques que codifiquen isoenzims SGT amb funcions especialitzades. En aquest treball es posa a punt un sistema d'expressió de l'enzim SISGT1 en Escherichia coli, per tal que posteriorment es pugui procedir a la seva purificació i a la caracterització bioquímica de la seva activitat enzimàtica de glucosilació enfront de diferents substrats.

Paraules clau: esterol, Gateway, plasmidi, proteïna recombinant.

\footnotetext{
${ }^{1}$ Graduada en Farmàcia (elenamuroblanc@gmail.com).
} 


\section{Introducció}

\subsection{Esterols}

Les plantes contenen diferents esterols, components essencials de la membrana cel-lular, dels quals els majoritaris són el $\beta$-sitosterol, l'estigmasterol i el campesterol. En algunes solanàcies el colesterol també es troba en grans quantitats (Benveniste et al.; 2004; Moreau et al., 2002; Schaller et al., 2003; Sonawane et al., 2016). Aquests compostos interaccionen amb fosfolípids i esfingolípids (Furt et al., 2010) i regulen així la permeabilitat i la flü̈desa de les membranes i, per tant, la seva estructura i funció (Laloi et al., 2006; Schaller, 2003). D’altra banda, el campesterol és precursor dels brassinoesteroides (Schaller et al., 1998), hormones necessàries per al control del desenvolupament i la morfogènesi vegetal (Vriet et al., 2015).

Els esterols són triterpens; per tant, es formen a partir de l'isopentenil pirofosfat (IPP) i el dimetilalil pirofosfat (DMAPP). Aquests precursors poden ser sintetitzats per dues vies metabòliques: la via citosòlica, anomenada ruta del mevalonat (MVA); o la via plastídica, anomenada ruta del metileritritol 4-fosfat (MEP) (Hemmerlin et al., 2012, Vranová et al., 2013). La formació dels esterols té lloc a partir d'IPP i DMAPP citosòlics. Després de diferents reaccions, s'arriba al cicloartenol, el primer intermediari cíclic precursor dels esterols vegetals (Ohyama et al., 2009) (figura 1).

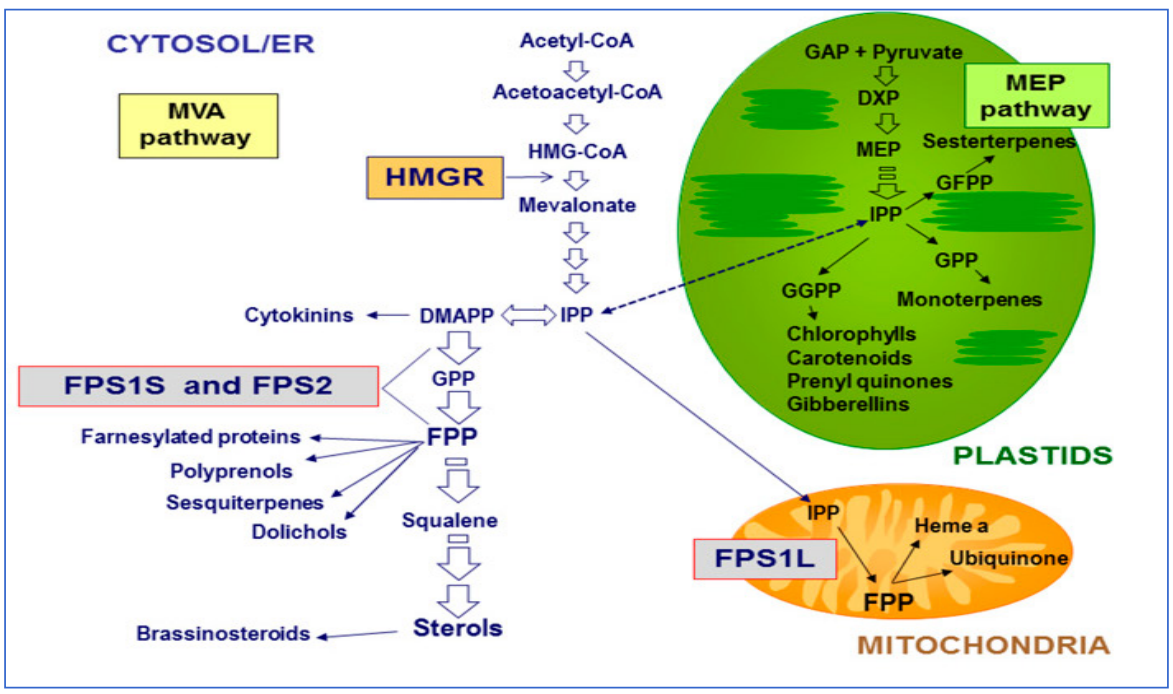

Figura 1. Esquema simplificat de les rutes MVA i MEP per a la formació d'isoprenoides (Manzano et al., 2016).

Els esterols presenten una estructura química derivada del ciclopentanoperhidrofenantrè. Aquesta estructura està composta per un nucli rígid de quatre anells: tres hexàgons i un pentàgon. Cal destacar dues posicions: en el C3 es troba un grup hidroxil lliure; i en el C17, una cadena lateral alifàtica de vuit a deu carbonis. El número de grups metil en la posició C4 (Bouvier-Nave et al., 2009), el tipus de grup alquil de la posició C24 i les insaturacions de la cadena lateral alifàtica canvien entre els diferents tipus d'esterols (Nes, 2011) (figura 2).

Quan l'hidroxil de la posició C3 es troba lliure, parlem d'esterols lliures (de l'anglès, FS). En canvi, quan es troba un grup químic unit a aquesta posició, parlem d'esterols conjugats. Els esterols conjugats es diferencien en tres tipus: èsters d'esterols (SE), glucòsids d'esterols (SG) i acilglucòsids d'esterols (ASG). Els SE contenen un àcid gras unit mitjançant un enllaç de tipus èster; els SG es troben units a un sucre mitjançant un enllaç glicosídic; i, finalment, els ASG són derivats dels SG, en els quals l'hidroxil del C6 del sucre es troba esterificat amb un àcid gras (Benveniste et al., 2004; Moreau et al., 2002) (figura 2). 


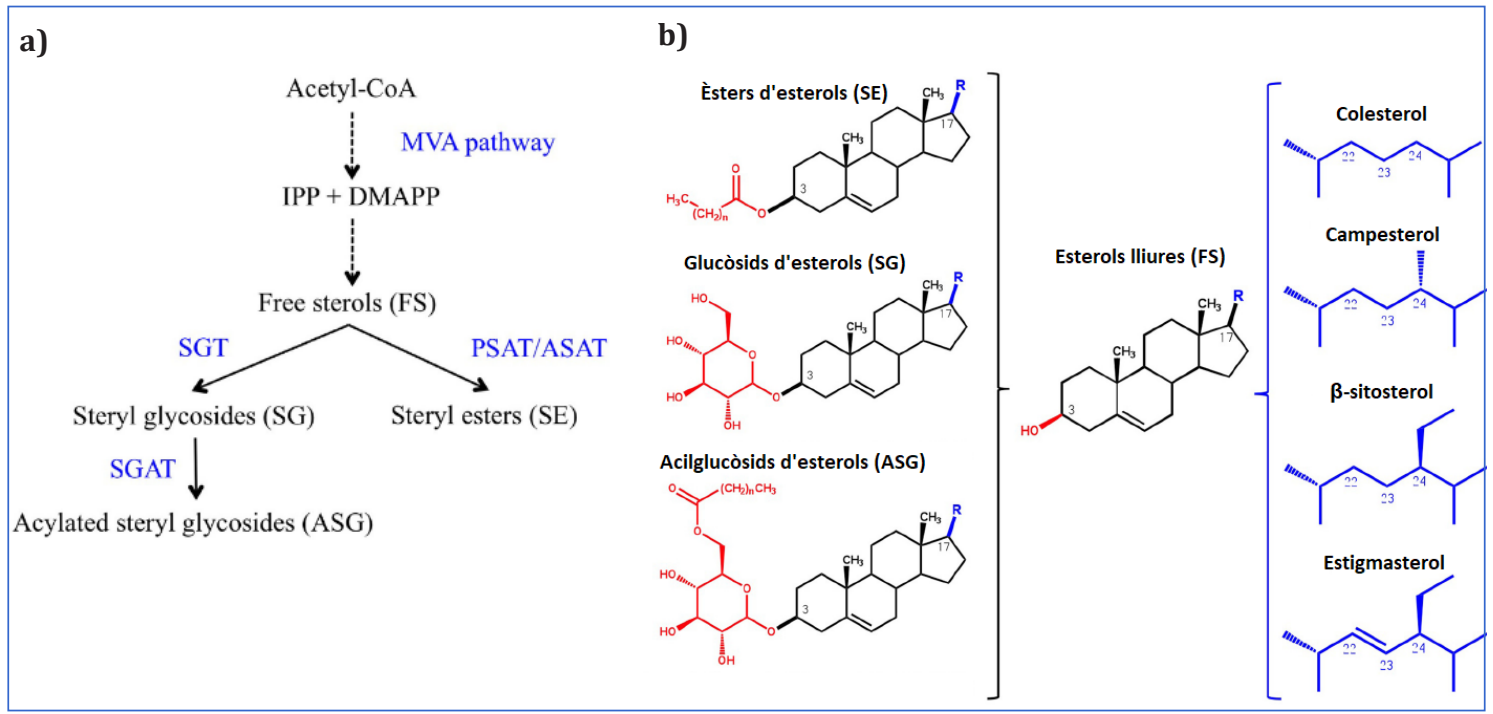

Figura 2. a) Esquema simplificat de la biosíntesi d'esterols conjugats (Ramírez-Estrada et al., 2017). b) Estructura química dels esterols vegetals (adaptat de Ramírez-Estrada et al., 2017). En vermell s'indica el grup hidroxil del C3 i els substituents units a aquests als SE, SG i ASG. En blau es mostren les cadenes laterals unides al C17, que formen els quatre esterols principals de les plantes.

Els SE s'emmagatzemen en vesícules lipídiques al citoplasma i formen un reservori per mantenir uns nivells fisiològics de FS (Bouvier-Nave et al., 2009). En canvi, els FS, SG i ASG es troben majoritàriament a les membranes cel-lulars, per tal de mantenir la seva estructura i funcionalitat (Schaller, 2004).

Els canvis en les proporcions relatives d'esterols alteren la fluïdesa i la permeabilitat de la membrana plasmàtica (Grosjean et al., 2015; Roche et al., 2008), de manera que participen en la regulació de la difusió i el transport actiu de metabòlits, i de l'activitat de les proteïnes associades a la membrana (Carruthers, 1984; Cooke et al., 1990; Grandmougin-Ferjani et al., 1997). Aquest fet dona un paper primordial als nivells d'esterols de membrana en la resposta adaptativa de les plantes davant l'estrès.

A més, els esterols participen en la modulació del creixement i el desenvolupament de les plantes, ja que el campesterol és precursor de les hormones brassinoesteroides (Yokota, 1997) i que els canvis en la composició d'esterols afecten processos com ara l'expansió, la divisió i la polaritat cellular (Men et al., 2008); el trànsit vacuolar (Li et al., 2014), la connectivitat intercel-lular (Grison et al., 2015) i la formació de parets celllulars (Schrick et al., 2012), entre d'altres.

\subsection{Esterols glucosilats (SG)}

El contingut total i les proporcions relatives dels SG varien entre espècies, òrgans i condicions de creixement. A més, el perfil dels SG no sempre concorda amb la composició d'esterols totals al mateix teixit, fet que indica que hi ha preferència pels substrats subjectes a glucosilació (Moreau et al., 2002; Nyström et al., 2012).

Els SG formen part de les membranes cellulars, però la seva funció encara no es coneix completament. Es pensa que la proporció relativa de FS i SG és important per a la regulació de les propietats de la membrana celllular (Grille et al., 2010; Grosjean et al., 2015; Moreau et al., 2002) i, per tant, en els diferents processos associats a aquesta, com ara l'adaptació a condicions d'estrès (Moreau et al., 2002; Li et al., 2014; Singh et al., 2016), la senyalització i el transport, etc.

En la majoria de les espècies vegetals no es troben grans quantitats de SG i ASG (Nyström et al., 2012), però el gènere Solanum en pot arribar a acumular grans quantitats (Duperon et al., 1984; Whi- 
taker, 1988; Whitaker et al., 2008). De totes maneres, encara es desconeix la seva funció biològica. $S$ 'ha suggerit que poden ser necessaris per a la protecció enfront de l'efecte tòxic dels glucoalcaloides esteroidals, com l' $\alpha$-tomatina (Blankemeyer et al., 1997; Keukens et al., 1995).

La síntesi de SG està catalitzada per les UDP-glucoses esterol-glucosiltransferases (SGT; EC 2.4.1.173), que transfereixen un residu de glucosa de la UDP-glucosa al grup hidroxil lliure del C3 dels FS. Aquesta reacció ha estat associada especialment a la membrana cellular, tot i que també s'ha descrit la presència d'isoenzims de SGT solubles al citosol (Grille et al., 2010; Li et al., 2014; Madina et al., 2007). Els isoenzims SGT s'han clonat i caracteritzat en poques espècies, entre les quals destaquen la planta model Arabidopsis thaliana (DeBolt et al., 2009; Stucky et al., 2014; Warnecke et al., 1997) i dues espècies de la família de les Solenaceae, Withania somnifera (Chaturvedi et al., 2012; Sharma et al., 2007) i Solanum lycopersicum cv. Micro-Tom (Ramírez-Estrada et al., 2017). Aquesta última ha estat descrita pel grup de recerca en el qual s'ha realitzat aquest treball. Els estudis suggereixen que les plantes contenen petites famílies multigèniques que codifiquen isoenzims SGT amb funcions especialitzades.

\subsection{UDP-glucosa: esterol-glucosiltransferases de Solanum lycopersicum}

S'han identificat i caracteritzat funcionalment quatre gens que codifiquen per SGT en tomàquet (Solanum lycopersicum cv. Micro-Tom), anomenats SISGT1-4 (Ramírez-Estrada et al., 2017). Aquests isoenzims tenen activitat tant in vitro com in vivo. Aquests gens s'expressen de manera diferenciada en diferents teixits de la planta, durant el creixement i la maduració del fruit. A més, l'expressió dels gens SISGT2 i SISGT4 es veu induïda en condicions d'estrès; en canvi, l'expressió dels gens SISGT1 i SISGT3 no es veu alterada davant els tractaments provats.

Els estudis de localització subcel-lular demostren que es tracta de proteïnes parcialment solubles que interaccionen amb la membrana plasmàtica a través de forces febles. L'isoenzim que més interacciona amb la membrana és SISGT3, seguidament de SISGT1. En canvi, SISGT2 i SISGT4 es troben preferiblement al citosol (Ramírez-Estrada et al., 2017).

Mutants nuls per les dues SGT d'A. thaliana (UGT80A2 i UGT80B1) s'han utilitzat per estudiar les SGT de tomàquet. Les últimes conclusions obtingudes són que l'expressió de SISGT4 en A. thaliana té sobre les llavors efectes similars als vists amb la sobreexpressió de l'enzim UGT80B1; per tant, se suposa que SISGT4 té preferència per glucosilar brassicasterol.

S'ha observat que aquestes línies mutants presenten una àrea foliar de les plàntules menor a l'àrea de les fulles en soca salvatge (wild type). En canvi, la sobreexpressió de SISGT1 i SISGT2 en les línies d'A. thaliana mutants reverteix parcialment aquest fenotip. Aquesta observació porta a pensar que els isoenzims SISGT1 i SISGT2 tenen funcions similars i relacionades amb el desenvolupament vegetatiu de la planta, però diferents de les de SISGT4, ja que generalment no afecten el fenotip de les llavors (resultats no publicats).

Pel que fa a SISGT3, les llavors transgèniques sobreexpressores d'aquest isoenzim presenten deformacions que dificulten la seva viabilitat, fet relacionat amb el possible efecte nociu de l'acumulació d'esterols glucosilats, però es necessiten més estudis per confirmar aquesta hipòtesi (resultats no publicats).

Aquests resultats de treballs anteriors del grup fan pensar que els isoenzims SGT de tomàquet tenen funcions que parcialment s'encavalquen, però alhora són especialitzades, fet en part atribuïble a les diferents preferències de substrats. Per tal de confirmar aquest supòsit, aquest treball vol continuar amb la caracterització funcional d'aquests enzims, concretament amb la de l'isoenzim SISGT1, que és el que s'expressa de manera més generalitzada i a un nivell més alt. 


\section{Objectius del treball}

El principal objectiu d'aquest treball és posar a punt un sistema d'expressió de l'enzim SISGT1 en Escherichia coli, per tal que posteriorment es pugui procedir a la seva purificació i a la caracterització bioquímica de la seva activitat enzimàtica de glucosilació enfront de diferents esterols com a substrat. Per això es proposa:

- Dissenyar i construir un plasmidi recombinant per expressar en Escherichia coli el gen d'interès sota el control d'un promotor induïble.

- Optimitzar les condicions per induir l'expressió del cDNA que codifica per SISGT1.

- Intentar solubilitzar la proteïna obtinguda, ja que es necessita d'aquesta manera per tal de mesurar la seva activitat.

\section{Material i mètodes}

\subsection{Medis de cultiu bacterià}

Tot el procés es duu a terme amb diferents soques d'Escherichia coli. El medi de cultiu líquid utilitzat és l'LB (Luria-Bertani), pH 7,5, que conté:

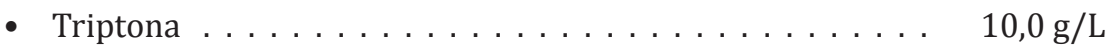

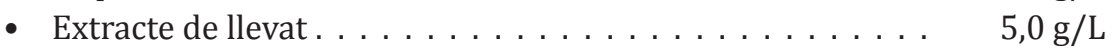

- Clorur sòdic . . . . . . . . . . . . . . . . . . 10,0 g/L

En el cas dels cultius sòlids en placa de petri, s'afegeix agar a una concentració final de $15 \mathrm{~g} / \mathrm{L}$. En els casos en què cal l'ús d'un antibiòtic, les concentracions utilitzades són:

- Gentamicina . . . . . . . . . . . . . . . . $25 \mu \mathrm{g} / \mathrm{mL}$

- Kanamicina . . . . . . . . . . . . . . . $25 \mu \mathrm{g} / \mathrm{mL}$

- Cloramfenicol . . . . . . . . . . . . . . $10 \mu \mathrm{g} / \mathrm{mL}$

\subsection{Disseny dels encebadors per obtenir el cDNA de SISGT1}

La seqüència que codifica el cDNA per SISGT1 es troba inserida en el plasmidi pEarleyGate100. Com que es vol clonar per recombinació mitjançant la tècnica de Gateway, s'ha d'amplificar la seqüència codificant amb encebadors que portin les seqüències de recombinació attB1 i attB2 als extrems.

\subsubsection{Encebador directe (forward primer)}

\section{SGT1-attB1: GGGG ACA AGT TTG TAC AAA AAA GCA GGC TTC ATGGATCAAACTTCGCCGG}

En negreta es destaca la seqüència attB1, a continuació hi ha dos nucleòtids (TC) que fan mantenir el marc de lectura i finalment es troba l'inici de la seqüència d'interès (ATG). Els quatre nucleòtids de guanina s'afegeixen per afavorir l'eficiència de la recombinació. Té una temperatura de fusió de $61,5^{\circ} \mathrm{C}$. 


\subsubsection{Encebador invers (reverse primer)}

\section{SGT1-attB2: GGGG AC CAC TTT GTA CAA GAA AGC TGG GTG GGTCGAGGAACACCCAAAG}

En aquest cas es troba primer la regió que codifica per attB2 i, a continuació, la seqüència inversa al final de la cadena complementària del cDNA d'interès. Té una temperatura de fusió de $62,2^{\circ} \mathrm{C}$.

\subsection{Amplificació del cDNA de SISGT1 del plasmidi pEarleyGate100}

El cDNA SISGT1 s'amplifica per mitjà d'una reacció en cadena de la polimerasa, més coneguda com a PCR (polymerase chain reaction). La temperatura d'hibridació es troba $5^{\circ} \mathrm{C}$ per sota de la temperatura de fusió més baixa del parell d'encebadors.

\subsubsection{Amplificació amb les polimerases Green Taq i AccuPrime ${ }^{\mathrm{TM}}$ Taq}

Primerament es fa una prova amb Green Taq DNA polymerase (GenScript $囚$ ), una polimerasa sense activitat de correcció de proves (proofreading), però amb una alta estabilitat tèrmica i un alt rendiment per PCR.

Se segueix el protocol del fabricant de la polimerasa (GenScript, 2010). Es proven dues temperatures d'hibridació: la teòrica $\left(56,5^{\circ} \mathrm{C}\right)$ i una temperatura més baixa, menys restrictiva $\left(53,5^{\circ} \mathrm{C}\right)$.

Els passos de desnaturalització, hibridació i extensió es repeteixen durant trenta-dos cicles per obtenir prou DNA, ja que només s'està fent una prova inicial i no preocupa gaire si es produeix una mutació aleatòria.

A continuació es repeteix la reacció d'amplificació amb una altra polimerasa de fidelitat més alta. Se segueix el protocol descrit per l'empresa fabricant de la polimerasa: Invitrogen ${ }^{\mathrm{TM}}$ AccuPrime $^{\text {TM }}$ Taq DNA Polymerase, del laboratori Thermo Fisher Scientific $®$, que inclou la Platinum Taq DNA-polimerasa, una polimerasa d'alta fidelitat amb activitat proofreading (Invitrogen, 2010).

Es proven diferents temperatures d'hibridació dels encebadors i diferents concentracions de cDNA.

TAULA 1. CONCENTRACIONS DE CDNA I TEMPERATURES D'HIBRIDACIÓ PER A LA REACCIÓ DE PCR AMB ACCUPRIMETM TAQ DNA POLIMERASA.

\begin{tabular}{|l|c|c|}
\hline \multicolumn{1}{|c|}{ Tub } & $\begin{array}{c}\text { Concentració } \\
\text { de cDNA }(\mathbf{n g} / \boldsymbol{\mu L})\end{array}$ & $\begin{array}{c}\text { Temperatura } \\
\mathbf{d}^{\prime} \text { hibridació }\left({ }^{\circ} \mathbf{C}\right)\end{array}$ \\
\hline Control & - & 50 \\
\hline 5 I & 5 & 50 \\
\hline 5 II & 5 & 51,1 \\
\hline 50 I & 50 & 50 \\
\hline 50 II & 50 & 51,1 \\
\hline
\end{tabular}

En aquest cas, es fan trenta cicles per obtenir prou DNA i evitar mutacions aleatòries.

\subsubsection{Anàlisi dels productes d'amplificació per electroforesi en gel d'agarosa}

Es prepara un gel d'agarosa a l'1\% en tampó Tris - àcid bòric - EDTA (TBE) 1X. Després de mesclar el TBE i l'agarosa dins un erlenmeyer, la mescla es porta a ebullició en un forn microones. A continuació 
s'afegeix el colorant SYBR $®$ Safe a raó d'1 $\mu \mathrm{L}$ per cada $12 \mathrm{~mL}$ de solució, es barreja i s'aboca a la cubeta. S'introdueix la pinta adequada per fer els pous i es deixa solidificar a temperatura ambient. El colorant utilitzat és un agent intercalant del DNA; per tant, s'ha de manipular seguint les normes de seguretat per al seu ús i posterior rebuig.

Les condicions de l'electroforesi depenen de la finalitat d'aquesta. Si simplement es vol visualitzar el resultat d'una reacció de PCR, es pot fer córrer el DNA a un voltatge elevat (80-90 V). En canvi, si a continuació de l'electroforesi es vol purificar el fragment amplificat a partir del gel, s'han d'obtenir bandes ben definides per tal d'evitar contaminació, i això s'assoleix amb voltatges baixos (50-60 V). L'electroforesi es desenvolupa amb el tampó TBE 1X.

Les mostres provinents de la PCR amb la polimerasa Green Taq no s'han de tenyir perquè aquesta ja porta incorporat un colorant que permet visualitzar la migració del front de l'electroforesi. Es carreguen $10 \mu \mathrm{L}$ de cada mostra i $9 \mu \mathrm{L}$ del marcador GeneRuler 1 Kb DNA Ladder de Thermo Fisher Scientific ${ }^{\circledR}$. En el cas de les mostres provinents de la PCR amb AccuPrime ${ }^{\mathrm{TM}}$ Taq DNA Polimerasa, abans de carregar les mostres al gel se'ls ha d'afegir el colorant 6X TriTrack DNA Loading Dye, del laboratori Thermo Fisher Scientific ${ }^{\circledR}$, a raó d'1 $\mu \mathrm{L}$ de colorant per cada $5 \mu \mathrm{L}$ de producte de PCR.

\subsubsection{Purificació dels fragments de DNA}

Es purifica el cDNA de SISGT1 a partir del volum restant de la reacció de PCR mitjançant el kit NucleoSpin ${ }^{\circledR}$ Gel and PCR Clean-up, del fabricant Macherey-Nagel $®$ (Promega Corporation, 2010b). Aquest protocol es basa en la unió del DNA a la membrana de sílice de la columna en presència de sals caotròpiques. Les contaminacions s'eliminen mitjançant rentats amb el tampó de neteja i finalment s'elueix el DNA en $30 \mu \mathrm{L}$ del tampó d'elució. A continuació es determina la concentració del DNA amb un espectrofotòmetre NanoDrop 1000 de Thermo Fisher Scientific ${ }^{\circledR}$.

\subsection{Clonació mitjançant la tècnica de Gateway}

El sistema de clonació Gateway es basa en la recombinació que permet l'intercanvi de seqüències flanquejades pels llocs de recombinació entre diferents vectors. Es necessiten les seqüències de recombinació adequades, anomenades att, que són les que s'han afegit al fragment de DNA amplificat. A continuació, mitjançant l'acció de les clonases LR i BP, es transfereix la seqüència d'interès al vector d'expressió.

\subsubsection{Reacció BP}

Es necessita la seqüència d'interès flanquejada per les seqüències attB1 i attB2 i un plasmidi anomenat donor vector que contingui les seqüències attP1 i attP2 flanquejant el gen $c c d B$, que codifica per una proteïna tòxica que inhibeix el creixement d'Escherichia coli. En aquest cas es fa sevir el pDONR ${ }^{\mathrm{TM}}$ 207, que conté un gen de resistència a la gentamicina per seleccionar les colònies transformades. L'enzim BP clonasa intercanvia les regions $a t t B \mathrm{i} a t t P \mathrm{i}$, en conseqüència, les seqüències entre plasmidis, de manera que s'obté un plasmidi recombinant amb la seqüència d'interès flanquejada per regions attL1 i attL2, que rep el nom d'entry vector. 


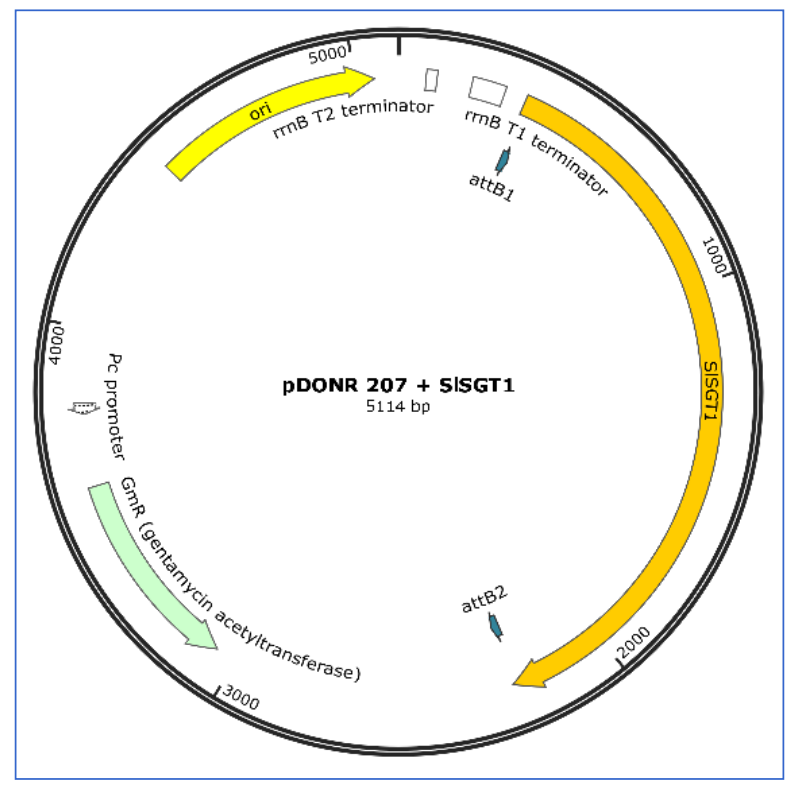

Figura 3. Construcció del plasmidi pDONRTM 207 amb l'insert de cDNA de SISGT1.

Es fa servir el Gateway ${ }^{\mathrm{TM}}$ BP Clonase ${ }^{\mathrm{TM}}$ II enzyme mix de Thermo Fisher Scientific $囚$, una mescla d'enzim i tampó que conté la proteïna integrasa recombinant del bacteriòfag lambda (Int), el factor hoste d'integració d'Escherichia coli (IHF) i el tampó. El kit inclou una solució de proteïnasa K (2 $\mu \mathrm{g} /$ $\mu \mathrm{L})$, que para la reacció de recombinació.

Se segueix el protocol del fabricant (Invitrogen, 2012). Com a producte de PCR es fan servir les mostres anomenades 5I i 5 II en l'apartat anterior.

\subsubsection{Transformació de la soca d'Escherichia coli TOP10 mitjançant xoc tèrmic}

Es tenen alíquotes de $50 \mu \mathrm{L}$ de cèl-lules d'Escherichia coli TOP10 competents a $-80{ }^{\circ} \mathrm{C}$. S'agafen dues d'aquestes alíquotes i es posen en gel durant 5 minuts, a continuació s'hi addiciona el producte de la reacció $\mathrm{BP}$ i es deixen reposar uns altres 5 minuts. Tot seguit s'aplica el xoc tèrmic: un bany a $42{ }^{\circ} \mathrm{C}$ durant 30". Immediatament després es posen les cèl-lules en gel durant 2 minuts. Finalment s'hi afegeixen $300 \mu \mathrm{L}$ de medi LB i s'incuba tot en agitació a $37^{\circ} \mathrm{C}$ durant 1 hora.

Transcorregut aquest temps, se sembren els cultius en plaques de petri de LB amb gentamicina i s'incuben a $37^{\circ} \mathrm{C}$ durant la nit. L'endemà, la presència de colònies resistents a l'antibiòtic confirma la recombinació dels plasmidis i la transformació posterior dels bacteris.

\subsubsection{Comprovació de la presència del plasmidi recombinant per PCR}

Se seleccionen sis colònies transformades i es propaguen per estria en una placa de petri amb LB i gentamicina. Es guarden d'aquesta manera a $4{ }^{\circ} \mathrm{C}$ durant un cert temps.

Amb la mateixa punta de pipeta es toca el fons d'un tub de PCR per dipositar-hi una petita quantitat de cèlllules i comprovar la presència del plasmidi recombinant mitjançant una reacció de PCR amb la polimerasa Green Taq (apartat 3.3.1). Les temperatures d'hibridació són: $52,2{ }^{\circ} \mathrm{C}$ per a les colònies resultants de $5 \mathrm{I}$ i $56,5^{\circ} \mathrm{C}$ per a les resultants de $5 \mathrm{II}$.

Finalment, es fan cultius de les colònies positives en $3 \mathrm{~mL}$ de medi LB i gentamicina, s'incuben en agitació a $37^{\circ} \mathrm{C}$ durant la nit i l'endemà se'n purifica el DNA plasmídic. Paral-lelament, es fa un altre cultiu de $3 \mathrm{~mL}$ per preparar estocs de les cèl-lules transformades. Per tal de fer l'estoc en glicerol, s'hi 
Edusfarm 11-12 (2019-2020), 223-245

ISSN: $1886-6271$

addicionen $750 \mu \mathrm{L}$ de glicerol al $50 \%$ i $750 \mu \mathrm{L}$ del cultiu líquid de la soca bacteriana transformada. Immediatament després, se submergeixen en nitrogen líquid i s'emmagatzemen a $-80^{\circ} \mathrm{C}$.

\subsubsection{Extracció de DNA plasmídic de cultiu bacterià líquid}

Per extreure el DNA plasmídic dels cultius s'utilitza el kit Wizard@ Plus SV Minipreps DNA Purification System, del laboratori Promega ${ }^{\circledR}$; se segueix el protocol del fabricant (Promega Corporation, 2010a). El DNA s'envia a seqüenciar al servei de seqüenciació del Centre de Recerca en Agrigenòmica (CRAG) per tal de comprovar que no hi ha canvis en la seqüència. Un cop obtinguda la seqüència del producte, es compara amb la seqüència teòrica mitjançant la funció d'alineació de seqüències del programa informàtic Serial Cloner.

\subsubsection{Reacció LR}

Per continuar amb el mètode de recombinació es necessita: el plasmidi anomenat entry clone, que en aquest cas és el pDONR ${ }^{\mathrm{TM}} 207 \mathrm{amb}$ la seqüència SISGT1 flanquejada per les regions attL, i un vector acceptor que servirà per expressar la proteïna, el plasmidi pET28 modificat (pET28-9HGW), el qual conté el promotor de la T7 RNA polimerasa. Les modificacions fetes són l'addició de la seqüència que codifica per nou histidines i les seqüències de recombinació $a t t R$ flanquejant el gen $c c d B$, de manera que la proteïna resultant s'expressa fusionada per l'extrem $\mathrm{N}$-terminal a la seqüència de nou histidines, que permetrà purificar-la mitjançant una cromatografia d'afinitat en una columna de níquel-agarosa. D'altra banda, aquest vector pET28-9HGW proporciona resistència a la kanamicina.

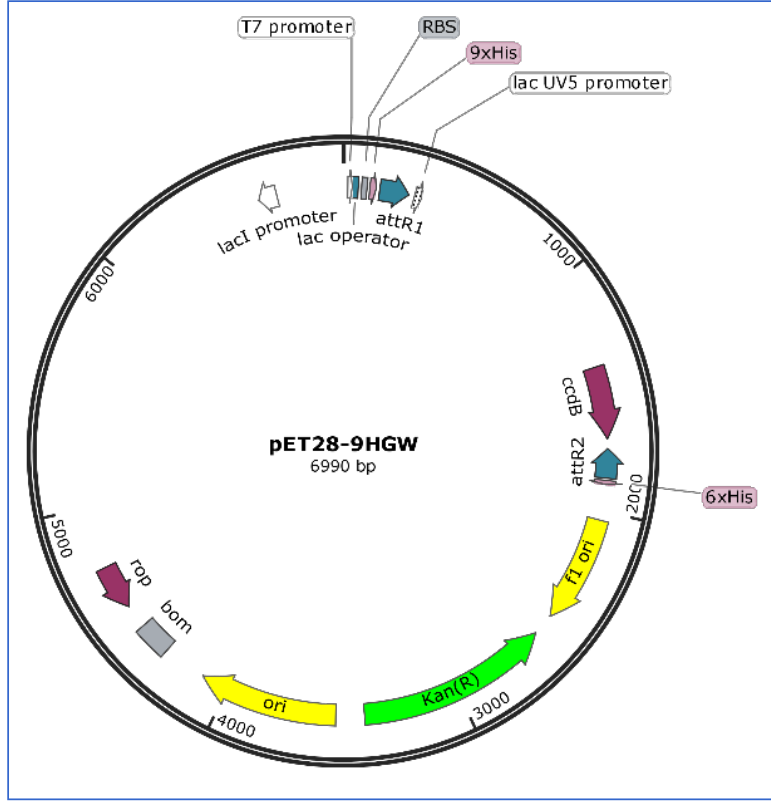

Figura 4. Esquema del vector pET28 modificat amb la cua de nou histidines i les regions attR1 i attR2.

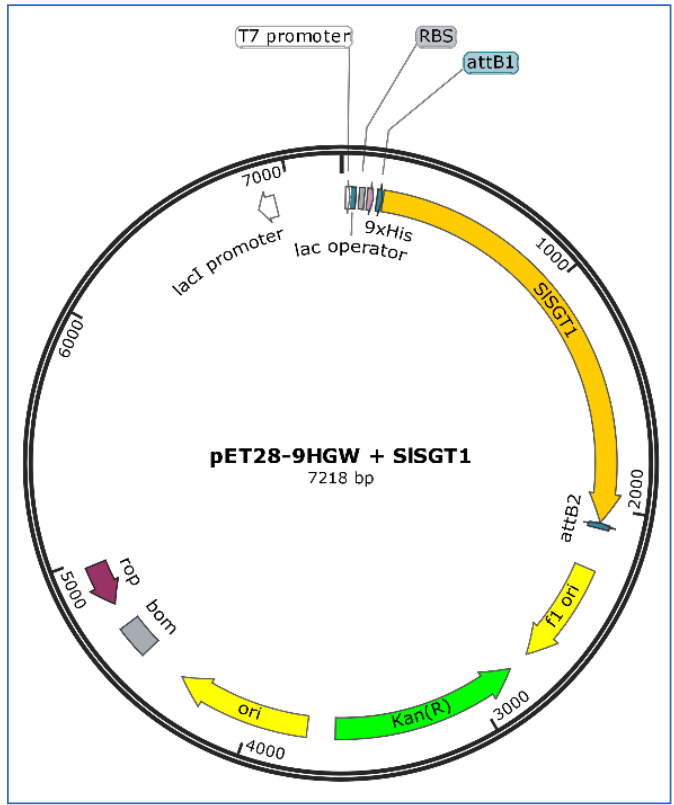

Figura 5. Construcció del plasmidi pET28-9HGW amb l'insert de cDNA de SISGT1.

L'intercanvi entre les regions attL i attR es duu a terme mitjançant l'enzim LR clonasa, de manera que s'obté el vector pET28-9HGW amb la seqüència d'interès.

Es fa servir el Gateway ${ }^{T M}$ LR Clonase ${ }^{T M}$ II enzyme mix de Thermo Fisher Scientific ${ }^{\circledR}$, una mescla d'enzim i tampó que conté la proteïna integrasa i excisionasa recombinant del bacteriòfag lambda 
(Int i Xis, respectivament), el factor hoste d'integració d'Escherichia coli (IHF) i el tampó. El kit inclou una solució de proteïnasa $\mathrm{K}(2 \mu \mathrm{g} / \mu \mathrm{L})$, que para la reacció de recombinació.

El procediment es duu a terme seguint les recomanacions del fabricant (Invitrogen, 2012). A continuació es transformen les soques desitjades d'Escherichia coli tal com s'ha descrit anteriorment i se seleccionen els bacteris transformats en plaques de petri amb LB i kanamicina. L'endemà en una placa de petri es fa estoc de diferents colònies, PCR amb la polimerasa Green Taq per comprovar la transformació i cultiu líquid de $3 \mathrm{~mL}$ per a l'extracció posterior de DNA plasmídic. Es repeteix la reacció de PCR amb aquest DNA extret per comprovar la presència de l'insert.

El DNA extret d'una de les colònies es porta a seqüenciar al servei de seqüenciació del CRAG amb els encebadors T7 i T7 terminal (encebadors universals per a aquest vector) per comprovar que el marc de lectura que codifica les nou histidines es manté en fase amb el que codifica la proteïna SISGT1. Un cop confirmat aquest punt, es prepara un estoc en glicerol de les cèlllules transformades.

\subsection{Expressió de la proteïna 9His-SISGT1}

La tècnica que es fa servir per expressar la proteïna d'interès es basa en el funcionament de l'operó lac d'Escherichia coli. En aquest cas, mitjançant l'addició d'IPTG (isopropil- $\beta$-D-1-tiogalactopiranòsid) s'activa el promotor lacUV5, que es troba al genoma de les soques d'Escherichia coli BL21 (DE3). Això provoca l'expressió de la T7 RNA polimerasa i aquesta reconeix el promotor T7 tardà en el plasmidi pET28-9HGW. En activar el promotor T7 tardà, s'expressa la proteïna introduïda al plasmidi, la proteïna 9His-SISGT1.

\subsubsection{Inducció de l'expressió de la proteïna recombinant 9His-SISGT1}

Abans d'induir l'expressió de la proteïna es fa un cultiu líquid de la soca BL21(DE3) d'Escherichia coli transformada amb el vector d'expressió en $3 \mathrm{~mL}$ de LB amb kanamicina i es deixa créixer durant la nit a $37^{\circ} \mathrm{C}$ en agitació. L'endemà s'escala aquest cultiu fins a $10 \mathrm{~mL}$. Aquest segon cultiu es deixa créixer a $37^{\circ} \mathrm{C}$ en agitació fins que s'obté una densitat òptica a una longitud d'ona de $600 \mathrm{~nm}\left(\mathrm{OD}_{600}\right)$ entre 0,5 i 0,6 unitats d'absorbància. Es considera que a aquests valors el cultiu es troba en creixement exponencial; per tant, és el moment d'induir l'expressió de la proteïna recombinant. Per fer-ho s'afegeix IPTG $100 \mathrm{mM}$ fins a obtenir una concentració final de 0,4 mM. A partir d'aquí, el cultiu es deixa créixer en agitació a temperatura ambient i es recullen alíquotes de $500 \mu \mathrm{L}$ en els temps desitjats. Les mostres se centrifuguen a $7.000 \mathrm{x}$ g durant 5 minuts i els precipitats es renten amb aigua destillada i es conserven a $-20^{\circ} \mathrm{C}$.

\subsubsection{Resuspensió de les cèlllules, lisi cel-lular i separació de fraccions soluble i insoluble de l'extracte proteic}

Les mostres de cèlllules es resuspenen en $200 \mu \mathrm{L}$ del tampó següent:

TAULA 2. COMPOSICIÓ DEL TAMPÓ DE RESUSPENSIÓ.

\begin{tabular}{|l|c|}
\hline Component & Concentració \\
\hline Tris-HCl, pH 8,0 & $100 \mathrm{mM}$ \\
\hline $\mathrm{MgCl}_{2}$ & $10 \mathrm{mM}$ \\
\hline EDTA & $1 \mathrm{mM}$ \\
\hline DTT & $1 \mathrm{mM}$ \\
\hline Tritó X-100 & $0,2 \%(\mathrm{v} / \mathrm{v})$ \\
\hline
\end{tabular}


Tot seguit, per tal de lisar les cèlllules i alliberar les proteïnes, les mostres són sonicades mitjançant una sonda U200Hcontrol del laboratori Ika Labortechnik ${ }^{\circledR}$, fent intervals de 30 segons durant 3 minuts. Es comprova que el tub queda transparent, fet que verifica la lisi celllular, i a continuació se centrifuguen les mostres durant 30 minuts a 15.000 x g a $4{ }^{\circ} \mathrm{C}$, de manera que la fracció soluble roman al sobrenedant i la fracció insoluble, al precipitat.

\subsection{Anàlisi de proteïnes per electroforesi en gel de poliacrilamida-SDS (PAGE)}

Un cop induïda l'expressió de la proteïna d'interès, es procedeix a visualitzar les proteïnes expressades durant el creixement bacterià mitjançant una electroforesi en gel de poliacrilamida-SDS (Laemmli, 1970).

\subsubsection{Preparació de gels d'acrilamida al $10 \%$}

El gel d'acrilamida s'utilitza per fraccionar les mostres de proteïnes mitjançant l'aplicació d'un corrent elèctric. El tractament de la mostra amb dodecilsulfat sòdic (SDS) fa que totes les proteïnes tinguin càrrega negativa i una relació càrrega-massa constant, de manera que se separen en funció de la seva massa molecular. El gel consta de dues parts: el gel separador a la part inferior, que serà on les proteïnes es fraccionaran, i el gel concentrador a la part superior.

\section{Gel separador}

TAULA 3. COMPONENTS DEL GEL SEPARADOR DE PROTEÏNES.

\begin{tabular}{|l|c|}
\hline \multicolumn{1}{|c|}{ Component } & Volum \\
\hline Acrilamida $30 \%$ & $3,33 \mathrm{~mL}$ \\
\hline Tris-HCl 1M, pH 8,8 & $2,50 \mathrm{~mL}$ \\
\hline $\mathrm{H}_{2} \mathrm{O}$ & $4,13 \mathrm{~mL}$ \\
\hline SDS $10 \%$ & $100 \mu \mathrm{L}$ \\
\hline APS $10 \%$ & $33,33 \mu \mathrm{L}$ \\
\hline TEMED & $6,67 \mu \mathrm{L}$ \\
\hline
\end{tabular}

Mitjançant una pipeta Pasteur s'aboca la mescla a la cubeta d'1,5 mm d'ample. Per evitar que quedin bombolles i que el marge superior del gel es deformi, es cobreix amb una capa d'isopropanol. Un cop format el gel, l'isopropanol s'elimina amb l'ajuda d'un paper de filtre.

\section{Gel concentrador}

TAULA 4. COMPONENTS DEL GEL CONCENTRADOR DE PROTEÏNES.

\begin{tabular}{|l|c|}
\hline \multicolumn{1}{|c|}{ Component } & Volum \\
\hline Acrilamida $30 \%$ & $390 \mu \mathrm{L}$ \\
\hline Tris-HCl $0,5 \mathrm{M}, \mathrm{pH} 6,8$ & $750 \mu \mathrm{L}$ \\
\hline $\mathrm{H}_{2} \mathrm{O}$ & $1,83 \mathrm{~mL}$ \\
\hline SDS $10 \%$ & $30 \mu \mathrm{L}$ \\
\hline APS $10 \%$ & $15 \mu \mathrm{L}$ \\
\hline TEMED & $3 \mu \mathrm{L}$ \\
\hline
\end{tabular}


Mitjançant una pipeta Pasteur s'aboca aquesta mescla sobre el gel anterior i s'hi introdueix la pinta de tefló per formar els pous. A continuació s'espera fins que el gel se solidifiqui.

\subsubsection{Preparació de les mostres}

El tampó de càrrega utilitzat és la solució de Laemmli.

TAULA 5. COMPOSICIÓ DEL TAMPÓ LAEMMLI 6X.

\begin{tabular}{|l|c|}
\hline \multicolumn{1}{|c|}{ Component } & Concentració \\
\hline Tris-HCl, pH 6,8 & $0,225 \mathrm{M}$ \\
\hline Glicerol & $54 \%(\mathrm{v} / \mathrm{v})$ \\
\hline $\mathrm{SDS}$ & $6 \%(\mathrm{p} / \mathrm{v})$ \\
\hline Blau de bromofenol & $0,015 \%(\mathrm{p} / \mathrm{v})$ \\
\hline$\beta$-mercaptoetanol & $15 \%(\mathrm{v} / \mathrm{v})$ \\
\hline $\mathrm{H}_{2} \mathrm{O}$ & q.s. \\
\hline
\end{tabular}

Aquesttampó s'utilitza per desnaturalitzar les mostresi carregar-les al pou.El $\beta$-mercaptoetanol redueix els ponts disulfur intramoleculars i intermoleculars; l'SDS addiciona càrregues negatives a les proteïnes; el blau de bromofenol fa visible el front de l'electroforesi i facilita la visualització de la càrrega de mostres al gel; finalment, el glicerol incrementa la densitat de les mostres per tal que romanguin als pous.

Les mostres es tracten amb la solució de Laemmli a una concentració final d'1X. Tot seguit es porten en un bloc a $100{ }^{\circ} \mathrm{C}$ durant 10 minuts, per acabar de desnaturalitzar les proteïnes.

\subsubsection{Electroforesi: separació de les proteïnes}

El tampó utilitzat per a l'electroforesi té la composició següent:

TAULA 6. COMPOSICIÓ DEL TAMPÓ PER A L’ELECTROFORES I AMB PROTEÏNES; $\mathrm{PH}<8,7$.

\begin{tabular}{|c|c|}
\hline Component & Concentració \\
\hline Glicina & $192 \mathrm{mM}$ \\
\hline Tris & $25 \mathrm{mM}$ \\
\hline SDS & $0,1 \%$ \\
\hline
\end{tabular}

Es carreguen quantitats equivalents de les mostres al gel. A més, es carrega el marcador PageRuler Prestained Protein Ladder, del laboratori Thermo Fisher Scientific $®$. L'electroforesi es duu a terme a $200 \mathrm{~V}$ fins al moment en què el front del colorant surt del gel. 


\subsubsection{Visualització de les proteïnes}

Un cop acabada l'electroforesi, se separa el gel dels suports i les proteïnes es tenyeixen amb la solució de blau de Coomassie durant 1 o 2 hores en agitació suau i protegit de la llum.

TAULA 7. COMPOSICIÓ DE LA SOLUCIÓ DE BLAU DE COOMASSIE.

\begin{tabular}{|l|c|}
\hline \multicolumn{1}{|c|}{ Component } & Concentració \\
\hline Blau de Coomassie & $0,05 \%$ \\
\hline Metanol & $40 \%$ \\
\hline Àcid acètic & $7 \%$ \\
\hline $\mathrm{H}_{2} \mathrm{O}$ destilllada & q.s. \\
\hline
\end{tabular}

Tot seguit es retira la solució anterior i se submergeix el gel en la solució destenyidora durant una nit, en agitació suau i protegit de la llum.

TAULA 8. COMPOSICIÓ DE LA SOLUCIÓ DESTENYIDORA.

\begin{tabular}{|l|c|}
\hline \multicolumn{1}{|c|}{ Component } & Concentració \\
\hline Metanol & $40 \%$ \\
\hline Àcid acètic & $10 \%$ \\
\hline $\mathrm{H}_{2} \mathrm{O}$ destil·lada & q.s. \\
\hline
\end{tabular}

Finalment es procedeix a capturar la imatge del gel amb les proteïnes tenyides mitjançant l'aparell ChemiDoc ${ }^{\mathrm{TM}}$ Touch Imagin System de BioRad®.

\section{Resultats i discussió}

\subsection{Obtenció del fragment de cDNA de SISGT1 flanquejat per attB1 i attB2}

Primerament es va fer una prova amb la Green Taq DNA Polimerasa (GenScript ${ }^{\circledR}$ ) (apartat 3.3.1) per comprovar si el fragment de cDNA que codificava per SISGT1 s'amplificava en afegir-hi les cues attB, mitjançant una reacció de PCR amb els encebadors dissenyats (apartat 3.2). Es van provar dues temperatures d'hibridació dels encebadors: la temperatura teòrica de $56,5^{\circ} \mathrm{C}$ i la de $53,5^{\circ} \mathrm{C}$, una mica menys restrictiva. A totes dues temperatures es va amplificar un fragment de la mida esperada: 1.942 parells de bases (figura 6).

Aconseguit el resultat positiu, es va repetir la PCR amb una polimerasa d'alta fidelitat: l'Accu-

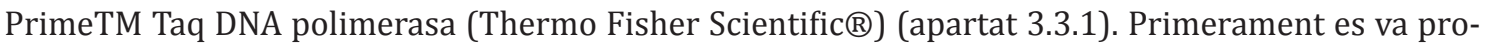
var la temperatura d'hibridació teòrica de $56,5^{\circ} \mathrm{C}$, però el resultat va ser negatiu. Tot seguit es van provar temperatures d'hibridació més baixes, de 50 i $51,1^{\circ} \mathrm{C}$, que resulten menys restrictives; a més, es van provar diferents concentracions de DNA motlle: $5 \mathrm{i} 50 \mathrm{ng} / \mu \mathrm{L}$. Aquest cop sí que es va obtenir un fragment de la mida esperada a tots els tubs (figura 7). 
GeneRuler $1 \mathrm{~Kb}$ DNA Ladder
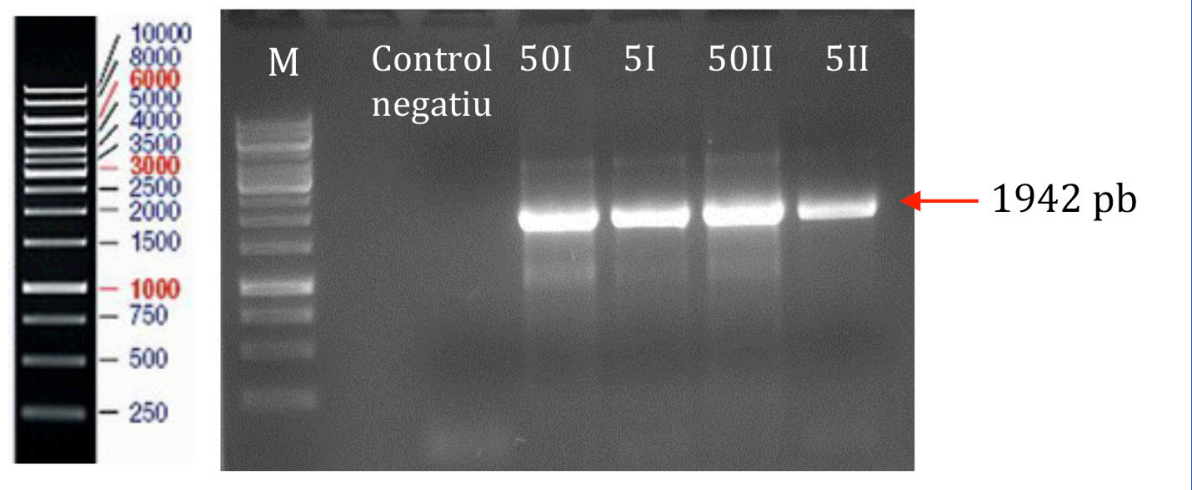

Figura 7. Amplificació de la seqüència que codifica SISGT1 de pEarleyGate100 amb AccuPrimeTM Taq DNA polimerasa. Condicions de l'electroforesi: gel d'agarosa 1\%, 80 V, 35 minuts. El carril M correspon al marcador.

\subsection{Clonació del cDNA SISGT1 mitjançant la tècnica de Gateway}

El DNA restant de la reacció anterior es va purificar mitjançant el kit NucleoSpin® Gel and PCR Clean-up de Macherey-Nagel@ (apartat 3.3.3) i amb aquest es va realitzar la recombinació mitjançant la tècnica de Gateway (apartat 3.4). Es va utilitzar el DNA procedent dels tubs 5I i 5II (figura 7). Per a la reacció BP es va fer servir el plasmidi pDONRTM 207 i es van transformar cèl-lules d'Escherichia coli TOP10 competents amb el plasmidi recombinant (apartat 3.4.2). La presència del plasmidi recombinant es va analitzar en quatre de les colònies transformades mitjançant una reacció de PCR amb la Green Taq DNA polimerasa de GenScript® (apartat 3.3.1) i els encebadors dissenyats a l'apartat 3.2. En tots els casos es va obtenir el fragment esperat de $1942 \mathrm{pb}$.

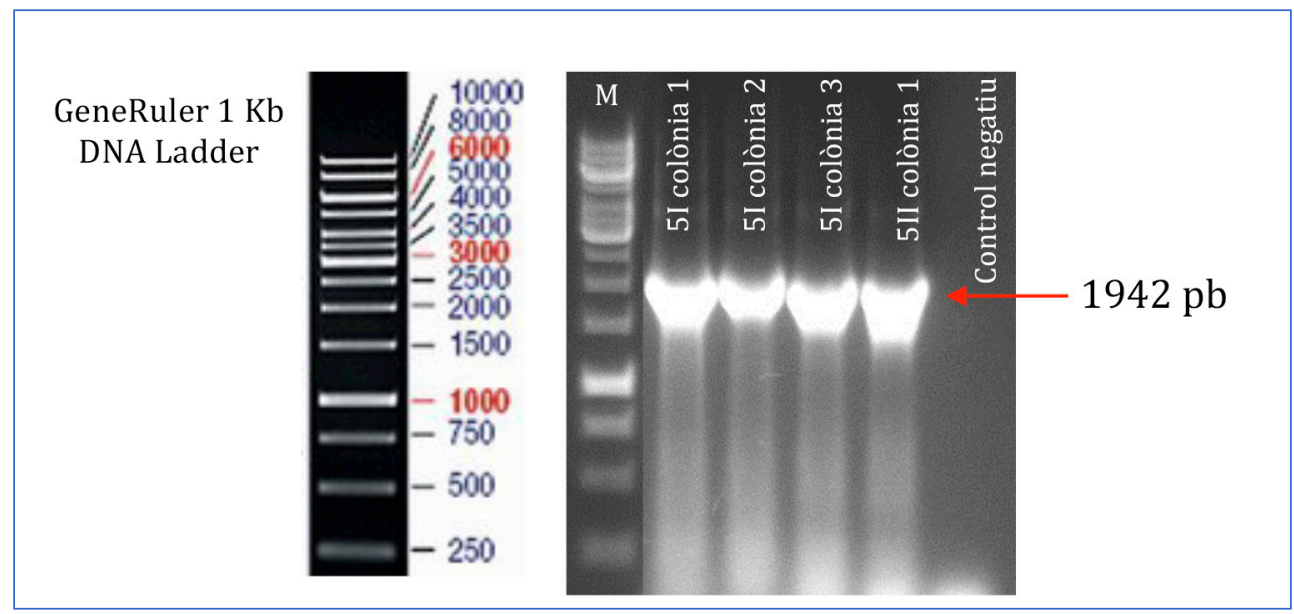

Figura 8: Comprovació de la transformació amb la reacció de recombinació BP amb Green Taq DNA polimerasa. Condicions de l'electroforesi: gel d'agarosa 1\%, 70V, 65 minuts. El carril M correspon al marcador.

L'obtenció de fragments d'amplificació de la mida adequada (figura 8) va verificar l'èxit de la reacció de recombinació amb el plasmidi pDONRTM 207. A continuació es van enviar a seqüenciar les mostres al servei de seqüenciació del CRAG. La comparació de la seqüència obtinguda amb l'original en el plasmidi pEarleyGate100 va demostrar que no hi havia mutacions a causa de la PCR. 
Edusfarm 11-12 (2019-2020), 223-245

ISSN: 1886-6271

Un cop vist que el resultat de la reacció BP era correcte, es va continuar amb la recombinació i es va procedir a realitzar la reacció LR (apartat 3.4.5), mitjançant la qual es va transferir el cDNA SISGT1 al plasmidi pET28-9HGW. A continuació es van transformar cèl-lules bacterianes de diferents soques, concretament Escherichia coli TOP10 i Escherichia coli BL21 (DE3) (apartat 3.4.2). El plasmidi pET28-9HGW proporciona un gen de resistència a la kanamicina que permet seleccionar les colònies transformades. De totes maneres, la presència del plasmidi recombinant en els bacteris resistents a kanamicina es va comprovar fent una reacció de PCR directament sobre les colònies bacterianes (apartat 3.4.3). En aquest cas, però, el resultat no va ser positiu, probablement per la baixa qualitat del DNA present a les mostres.

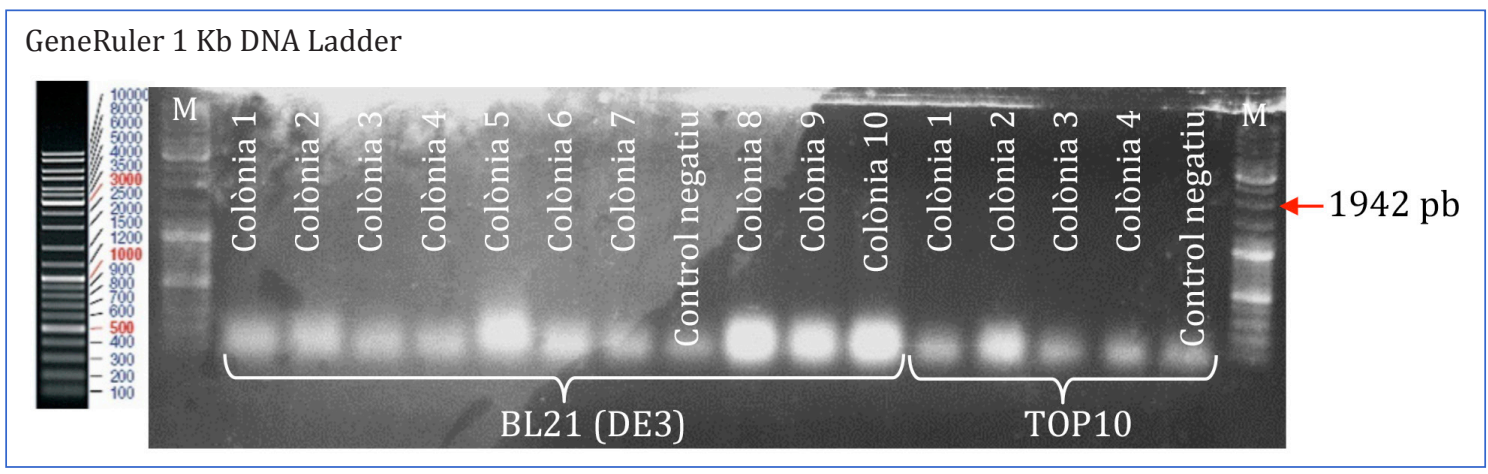

Figura 9. Comprovació de la transformació amb la reacció de recombinació LR amb Green Taq DNA polimerasa i DNA procedent de les colònies transformades. Condicions de l'electroforesi: gel d'agarosa 1\%, 80 V, 30 minuts. El carril M correspon al marcador.

Aconseguit el resultat negatiu de la prova anterior, es va procedir a repetir la reacció de PCR, però fent servir DNA plasmídic purificat a partir de cultius bacterians líquids (apartats 3.3.3 i 3.4.3). Aquesta vegada es van obtenir bandes de la mida esperada en totes, excepte en dues de les reaccions de PCR (figura 10).

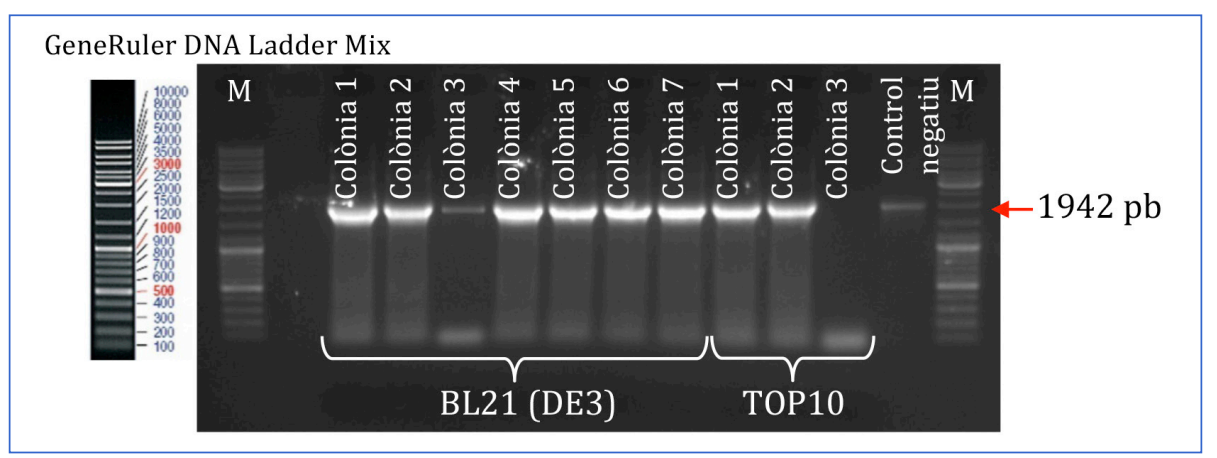

Figura 10. Comprovació de la transformació de les soques indicades amb la reacció de recombinació LR amb Green Taq DNA polimerasa i DNA plasmídic. Condicions de l’electroforesi: gel d'agarosa 1\%, 70 V, 50 minuts. El carril M correspon al marcador.

Es va continuar treballant amb el DNA extret de la colònia 5 de la soca d'Escherichia coli BL21 (DE3). Per a això, primer es va enviar a seqüenciar l'insert del plasmidi d'aquesta colònia amb els encebadors T7 i T7 terminal per confirmar que la inserció de la seqüència que codifica SISGT1 s'havia fet mantenint obert el marc de lectura que codifica les nou histidines del vector. A continuació es va procedir a transformar la resta de soques d'Escherichia coli BL21 (DE3) mitjançant la tècnica de xoc tèrmic (apartat 3.4.2). Les soques utilitzades van ser: 


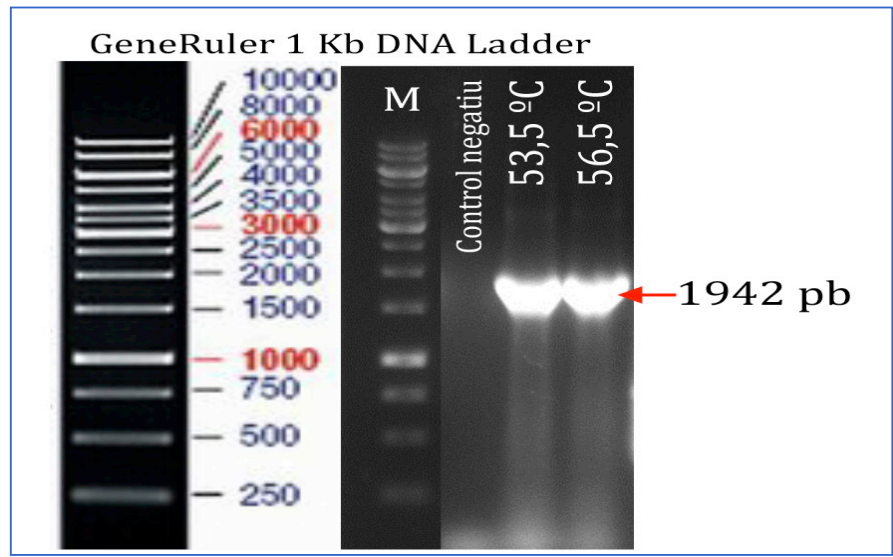

Figura 6: Amplificació de la seqüència que codifica SISGT1 de pEarleyGate100 amb Green Taq DNA polimerasa. Condicions de l'electroforesi: gel d'agarosa 1\%, 60V, 70 minuts. El carril M correspon al marcador.

- Escherichia coli BL21 (DE3) plysS; genotip: F- ompT hsdSB (rB- mB-) dcm gal, $\lambda$ (DE3), pLysS, Cmr): conté un gen que codifica pel lisozim T7, que redueix el nivell d'expressió de fons dels gens sota el control del promotor T7 sense interferir amb el nivell d'expressió després de la inducció per IPTG.

- Escherichia coli BL21 (DE3) Rosetta; genotip: F- ompT hsdSB (rB- mB-) gal dcm (DE3) pRARE (Camr): millora l'expressió de proteïnes eucariotes amb codons poc freqüents en Escherichia coli, mitjançant la proporció de tRNA per a aquests codons.

- Escherichia coli BL21 (DE3) CodonPlus RIL; genotip: F- ompT hsdS (rB- mB-) dcm+ Tetr gal endA Hte [argU ileY leuW Camr]: proporciona un control més estricte de l'expressió proteica, a més de contenir tRNA per als codons rars en Escherichia coli.

Aquestes soques tenen un gen que els proporciona resistència al cloramfenicol.

La transformació es va comprovar mitjançant una reacció de PCR directament sobre les colònies bacterianes (apartat 3.4.3) i, com s'observa en la figura 11, en totes les colònies es va amplificar el fragment SISGT1 de $1942 \mathrm{pb}$.

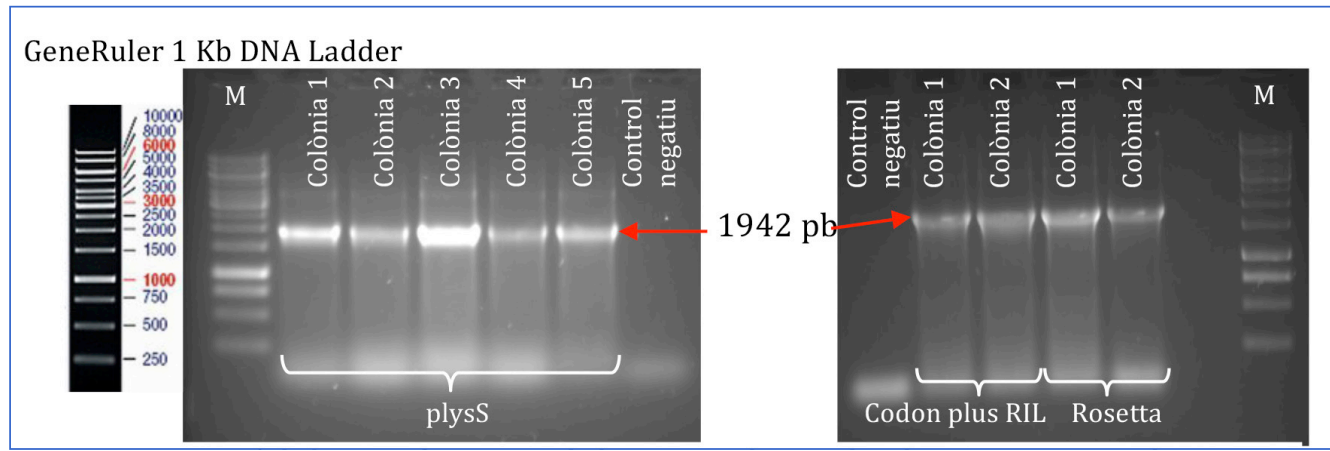

Figura 11. Comprovació de les transformacions de les soques plysS, CodonPlus RIL i Rosetta amb Green Taq DNA polimerasa. Condicions de l'electroforesi: gel d'agarosa 1\%, (esquerra) 80 V, 30 minuts; (dreta) $70 \mathrm{~V}, 40$ minuts. El carril M correspon al marcador.

En tots els casos es van generar estocs en glicerol com es descriu en l'apartat 3.4.3. 


\subsection{Expressió de la proteïna 9His-SISGT1}

Un cop transformades les soques d'expressió, es va procedir a induir la producció de la proteïna recombinant. Primerament es va induir a temperatura ambient i a una concentració d'IPTG de 0,4 mM (apartat 3.5.1). Les mostres es van recollir a temps zero, al cap de tres hores i després de tota la nit $(\mathrm{o} / \mathrm{n}$, de l'anglès over night), i es van lisar les cèlllules per obtenir els extractes de proteïna total (apartat 3.5.2), que es van analitzar mitjançant electroforesi en gel d'acrilamida-SDS (apartat 3.6). Es van sembrar 5 i $15 \mu \mathrm{L}$ de cada mostra. La mida esperada de la proteïna era de 75,7 kDa.

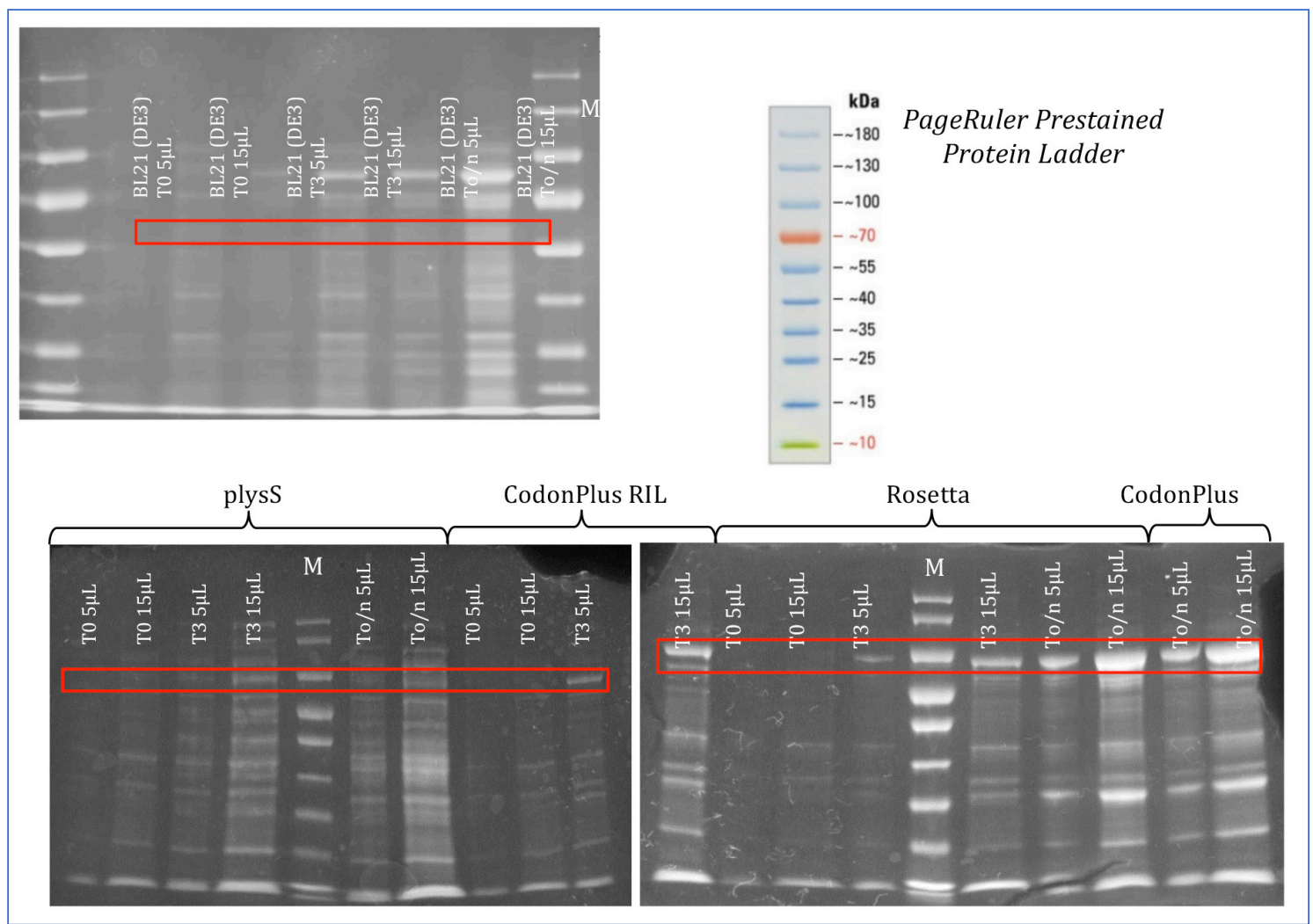

Figura 12: Anàlisi en gel de poliacrilamida-SDS dels extractes de proteïna total d'E. coli BL21 (DE3), E. coli BL21 (DE3) plyS, E. coli BL21 (DE3) CodonPlus RIL i E. coli BL21 (DE3) Rosetta. Inducció feta a temperatura ambient amb 0,4mM d'IPTG. Mostres recollides abans de la inducció $\left(\mathrm{T}_{0}\right)$, després de 3 hores $\left(\mathrm{T}_{3}\right)$ i over night $\left(\mathrm{T}_{\mathrm{o} / \mathrm{n}}\right)$. Els carrils M corresponen al marcador. En vermell es ressalta la zona on es troba la proteïna 9His-SISGT1.

Com es pot veure en la figura 12, es va detectar expressió de 9His-SISGT1 a totes les soques, però a diferents nivells, per això es va decidir continuar treballant per determinar si aquesta proteïna es produïa de manera soluble o insoluble en alguna de les soques provades. Es van obtenir les fraccions soluble i insoluble a partir dels extractes proteics totals (apartat 3.5.2) i alíquotes de les dues fraccions van ser analitzades per electroforesi en gel d'acrilamida-SDS.

A les figures 13 i 14 es pot veure que pràcticament la totalitat de la proteïna recombinant es troba de manera insoluble; per això es va seleccionar la soca que n'expressa més quantitat, BL21(DE3) CodonPlus RIL, i es va modificar el protocol d'inducció d'expressió de la proteïna recombinant amb la intenció d'obtenir una major quantitat de proteïna en la fracció soluble. 


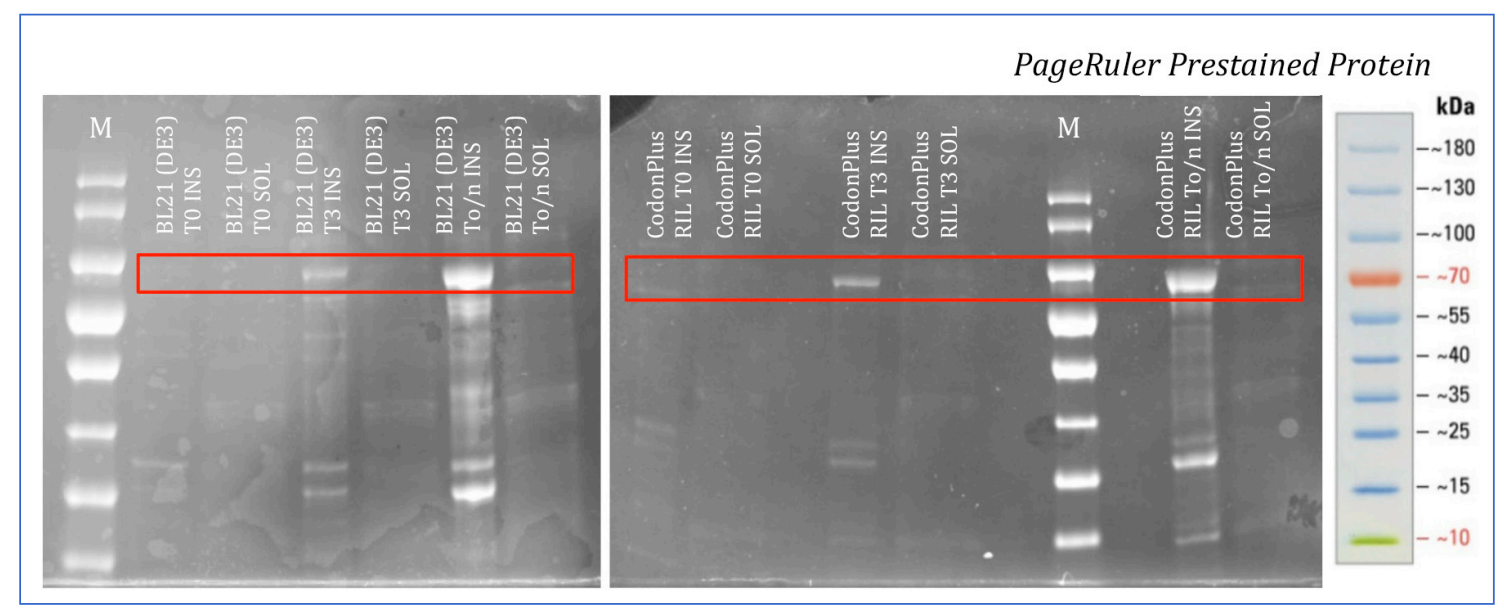

Figura 13. Fraccions soluble i insoluble de l'extracte de proteïna d'E. coli BL21 (DE3) i E. coli CodonPlus RIL. Inducció feta a temperatura ambient i 0,4m M d'IPTG. Mostres recollides abans de la inducció ( $\left.\mathrm{T}_{0}\right)$, després de tres hores $\left(\mathrm{T}_{3}\right)$ i over night $\left(\mathrm{T}_{\mathrm{o} / \mathrm{n}}\right)$. Els carrils $\mathrm{M}$ corresponen al marcador. En vermell es ressalta la zona on es troba la proteïna 9His-SISGT1.

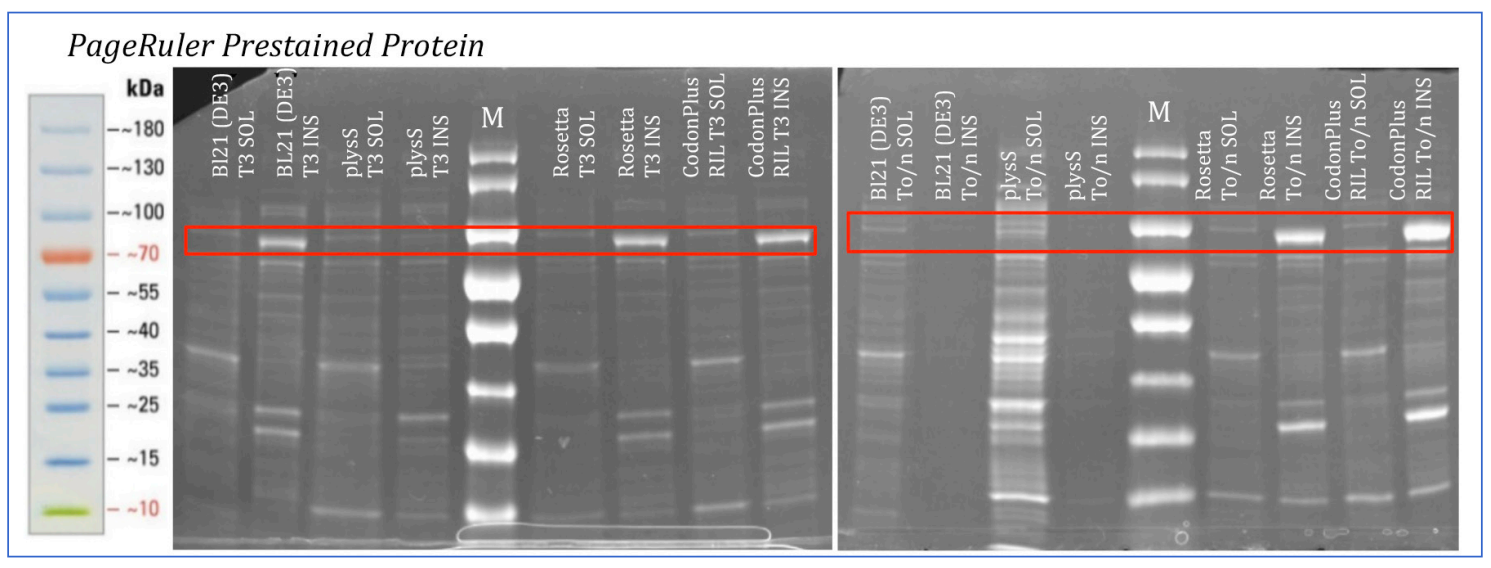

Figura 14. Fraccions soluble i insoluble de l'extracte de proteïna d'E. coli BL21 (DE3), E. coli BL21 (DE3) plyS, $E$. coli BL21 (DE3) CodonPlus RIL i E. coli BL21 (DE3) Rosetta. Inducció feta a temperatura ambient i 0,4 mM d'IPTG. Mostres recollides al cap de tres hores $\left(\mathrm{T}_{3}\right)$ i over night $\left(\mathrm{T}_{\mathrm{o} / \mathrm{n}}\right)$. Els carrils $\mathrm{M}$ corresponen al marcador. En vermell es ressalta la zona on es troba la proteïna 9His-SISGT1.

\subsection{Optimització de les condicions d'expressió i solubilització de la proteïna recombinant}

\subsubsection{Condicions de la inducció de la proteïna recombinant}

Un cop identificada la soca BL21(DE3) CodonPlus RIL com la que presenta més expressió de la proteïna 9His-SISGT1, es va procedir a fer un cultiu nou per induir posteriorment l'expressió de la proteïna recombinant. És freqüent que en expressar una proteïna recombinant en un sistema bacterià, aquesta es produeixi de manera insoluble, ja que se sintetitza ràpidament i no es plega correctament. Per això, una estratègia per intentar incrementar la quantitat de proteïna soluble és disminuir la seva velocitat de síntesi; per exemple, disminuint la temperatura del cultiu en el moment de la inducció i/o reduint la concentració de l'agent inductor (IPTG), entre altres variables. Per aquest 
Edusfarm 11-12 (2019-2020), 223-245

ISSN: 1886-6271

motiu, es va decidir provar les temperatures $4{ }^{\circ} \mathrm{C}, 16{ }^{\circ} \mathrm{C}$ i ambient; i reduir la concentració d'IPTG a $0,1 \mathrm{mM}$. Es van provar quatre condicions diferents a l'hora d'induir l'expressió de la proteïna, que es mostren a la taula 16. TAULA 9. CONDICIONS DE LA INDUCCIÓ D’EXPRESSIÓ
DE LA PROTEÏNA 9HIS-SLSGT1.

\begin{tabular}{|l|c|c|c|c|}
\hline & Condicions A & Condicions B & Condicions C & Condicions D \\
\hline [IPTG] $(\mathrm{mM})$ & 0,4 & 0,1 & 0,1 & 0,1 \\
\hline Temperatura $\left({ }^{\circ} \mathbf{C}\right)$ & 16 & 16 & $\mathrm{~T}^{\mathrm{a}}$ ambient & 4 \\
\hline Mostres & $\mathrm{T} 0,3 \mathrm{~h} \mathrm{i} \mathrm{o} / \mathrm{n}$ & $\mathrm{T} 0,3 \mathrm{~h} \mathrm{i} \mathrm{o} / \mathrm{n}$ & $\mathrm{T} 0,3 \mathrm{~h} \mathrm{i} \mathrm{o} / \mathrm{n}$ & $\mathrm{T} 0, \mathrm{o} / \mathrm{n} \mathrm{i} 3$ dies \\
\hline
\end{tabular}

Es van recollir els precipitats de cèllules en els temps indicats; en les condicions D es va decidir recollir mostres over night $\mathrm{i}$ al cap de tres dies, ja que la temperatura de $4{ }^{\circ} \mathrm{C}$ és molt baixa i alenteix el creixement d'Escherichia coli. Un cop recollides les mostres, es van tractar com es descriu a l'apartat 3.5.2, amb petites variacions en el tampó de resuspensió per intentar millorar la solubilitat de la proteïna: es va afegir glicerol al $10 \%$ per donar més densitat al tampó i es va augmentar la concentració de DTT a $5 \mathrm{mM}$, un agent reductor que trenca els ponts disulfur intramoleculars i intermoleculars.

Tot seguit es van preparar les mostres i es va procedir a fer l'anàlisi de proteïnes en les fraccions soluble i insoluble per electroforesi en gel de poliacrilamida-SDS, tal com s'ha descrit a l'apartat 3.6.

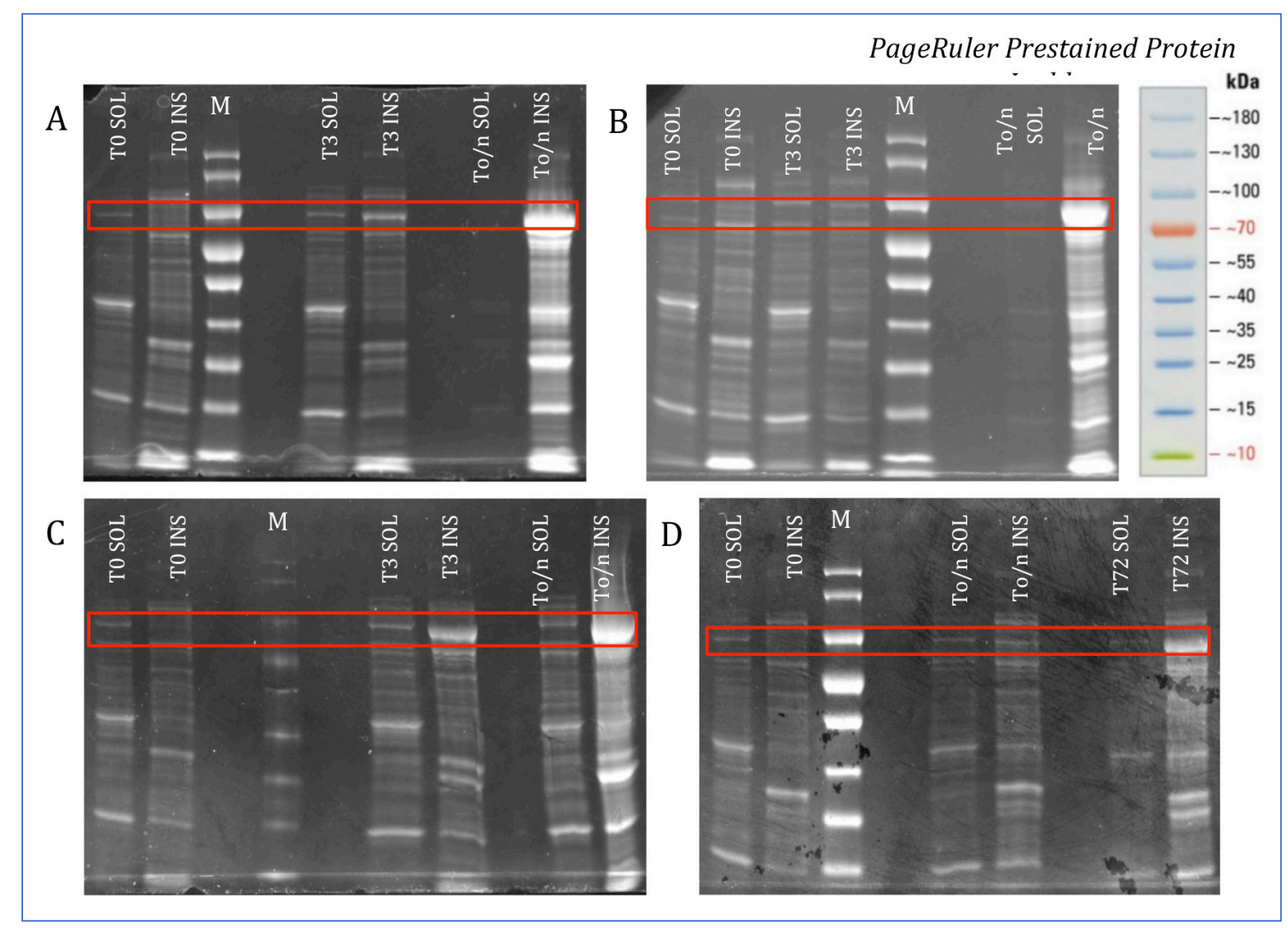

Figura 15. Fraccions soluble i insoluble de l'extracte de proteïnes d'E. coli BL21 (DE3) CodonPlus RIL. Inducció de l'expressió de la proteïna recombinant feta en les condicions A, B, C i D de la taula 16. Els carrils M corresponen al marcador. En vermell es ressalta la zona on es troba la proteïna 9His-SISGT1. 
Com s'observa en la figura 15, la proteïna recombinant continua sent majoritàriament insoluble, raó per la qual es pot concloure que cap de les modificacions assajades ha estat realment efectiva. Per això es va decidir modificar la manera d'obtenir els extractes solubles a partir dels cultius cel-lulars induïts: en comptes de trencar les cèllules bacterianes per tractament amb ultrasons, es va fer mitjançant un homogeneïtzador EmulsiFlex C5 d'Avestin®, conegut també com a French Press.

\subsubsection{Lisi cel-lular amb EmulsiFlex C5 (French Press)}

L'homogeneïtzador EmulsiFlex C5 és un aparell que trenca la membrana cel-lular mitjançant l'aplicació de pressions molt elevades. Per això es va fer un cultiu de $250 \mathrm{~mL}$ de la soca Escherichia coli BL21 (DE3) CodonPlus RIL transformada amb el plasmidi recombinant pET28-9HGW (SISGT1) i un altre cultiu d'Escherichia coli BL21 (DE3) CodonPlus RIL amb el plasmidi pET28-9HGW sense l'insert, que va servir com a control negatiu.

Els precipitats de cèlllules provinents dels cultius bacterians induïts a $16^{\circ} \mathrm{C}$ i $0,1 \mathrm{mM}$ IPTG es van resuspendre en $20 \mathrm{~mL}$ del tampó de resuspensió descrit a l'apartat 4.4.1. A continuació es va procedir a lisar les cèllules amb la French Press. Es va seguir el procediment descrit pel fabricant (Avestin ${ }^{\circledR}$ ), aplicant una pressió de 15.000 psi durant quatre cicles. A continuació es van obtenir les fraccions soluble i insoluble a partir d'alíquotes d'1 mL i es van analitzar per electroforesi en gel d'acrilamida-SDS.

Una anàlisi preliminar de la distribució de la proteïna 9His-SISGT1 per electroforesi en gel de poliacrilamida-SDS suggereix que aquesta es continua trobant de manera insoluble. S'hauran de provar altres condicions i/o tècniques per tal d'obtenir la proteïna recombinant a la fracció soluble.

\section{Conclusions}

1) S'ha construït un plasmidi recombinant per expressar en Escherichia coli, sota control d'un promotor induïble per IPTG, l'isoenzim UDP-glucosa: esterol-glucosiltransferasa 1 de S. lycopersicum cv Micro-Tom fusionat pel seu extrem N-terminal a una seqüència de nou histidines consecutives (9His-SISGT1), per tal que posteriorment es pugui procedir a la seva purificació i a la caracterització bioquímica de la seva activitat enzimàtica.

2) Entre les diferents soques bacterianes d'expressió provades (E. coli BL21(DE3), E. coli BL21(DE3) plysS, E. coli BL21(DE3) Rosetta i E. coli BL21(DE3) CodonPlus RIL), la soca BL21(DE3) CodonPlus RIL és la que produeix els nivells més elevats de la proteïna recombinant.

3) Pràcticament la totalitat de la proteïna 9His-SISGT1 expressada per la soca BL21(DE3) CodonPlus RIL d'Escherichia coli es troba en la fracció insoluble dels extractes cellulars, molt probablement perquè es tracta d'un enzim que en les cèlllules vegetals es troba parcialment associat a la membrana plasmàtica.

4) Els intents d'optimitzar les condicions d'expressió de la proteïna 9His-SISGT1, incloent-hi la temperatura i el temps d'inducció, la concentració de l'agent inductor de l'expressió, la tècnica de lisi cellular i la composició del tampó de solubilització, no han permès augmentar la quantitat d'aquesta proteïna soluble. 


\section{Bibliografia}

Benveniste, P. (2004) «Biosynthesis and accumulation of sterols». Annual Review of Plant Biology, 55(1), pp. 429-457.

BlAnKEMEYER, J.T. et al. (1997). «Effect of a-tomatine and tomatidine on membrane potential of frog embryos and active transport of ions in frog skin». Food and Chemical Toxicology, 35(7), pp. 639-646.

Bouvier-Nave, P. et al. (2009). «Involvement of the Phospholipid Sterol Acyltransferase1 in Plant Sterol Homeostasis and Leaf Senescence». Plant Physiology, 152(1), pp. 107-119.

Carruthers, A., Melchior, D.L. (1984). «How bilayer lipids affect membrane protein activity». Trends in Biochemical Sciences, 11(8), pp. 331-335.

Chaturvedi, P. et al. (2012). «Sterol glycosyltransferases-identification of members of gene family and their role in stress in Withania somnifera». Molecular Biology Reports, 39(10), pp. 9755-9764.

Cooke, D.T., Burden, R.S. (1990). «Lipid modulation of plasma membrane-bound ATPases». Physiologia Plantarum, 78(1), pp. 153-159.

DeBolt, S. et al. (2009). «Mutations in UDP-Glucose:Sterol Glucosyltransferase in A. Cause Transparent Testa Phenotype and Suberization Defect in Seeds». Plant Physiology, 151(1), pp. 78-87.

Duperon, R., Thiersault, M., Duperon, P. (1984). «High level of glycosylated sterols in species of Solanum and sterol changes during the development of the tomato». Phytochemistry, 23(4), pp. 743-746.

Furt, F., Simon-Plas, F., Mongrand, S. (2010). «Lipids of the Plant Plasma Membrane». The Plant Plasma Membrane. Plant Cell Monographs, 19, pp. 3-30.

GEnSCRIPT ®. (2010). Green Taq DNA Polymerase. Ed. Genscript ${ }^{\circledR}$ Disponible a:www.genscript.com/site2/ document/4387_20080507053158.pdf. (accedit: abril 2019).

Grandmougin-Ferjani, A., Schuler-Muller, I., Hartmann, M.A. (1997). «Sterol modulation of the plasma membrane HC-ATPase activity from corn root reconstituted into soybean lipids». Plant Physiology, 113(1), pp. 163-174.

GriLle, S. et al. (2010). «The functions of steryl glycosides come to those who wait: Recent advances in plants, fungi, bacteria and animals». Progress in Lipid Research, 49(3), pp. 262-288.

Grison, M. et al. (2015). «Specific Membrane Lipid Composition Is Important for Plasmodesmata Function in Arabidopsis». The Plant Cell, 27(4), pp. 1228-1250.

GrosjEAN, K. et al. (2015). «Differential Effect of Plant Lipids on Membrane Organization». Journal of Biological Chemistry, 290(9), pp. 5810-5825.

Hemmerlin, A., HaRwood, J., BACH, T. (2012). «A raison d'être for two distinct pathways in the early steps of plant isoprenoid biosynthesis?». Progress in Lipid Research, 51(2), pp. 95-148.

Invitrogen. (2010). AccuPrime TM Taq DNA Polymerase System. Ed. Life Technologies Corporation, Carlsbad Disponible a: https://assets.thermofisher.com/TFS-ssets/LSG/manuals/accuprimetaq_man. pdf. (accedit: març 2019).

InVitrogen. (2012). Gateway® Technology with clonase II. Ed. Life Technologies Corporation. Carlsbad Disponible a: http://tools.thermofisher.com/content/sfs/manuals/gateway_clonaseii_man.pdf. (accedit: març 2019).

KEUKEns, E.A. et al. (1995). «Molecular basis of glycoalkaloid induced membrane disruption». Biochimica et Biophysica Acta, 1240(2), pp. 216-228.

LAEMMLI U.K. (1970). «Cleavage of structural proteins during the assembly of the head of bacteriophage T4». Nature, 227(5259), pp. 680-685.

LALOI, M. et al. (2006). «Insights into the Role of Specific Lipids in the Formation and Delivery of Lipid Microdomains to the Plasma Membrane of Plant Cells». Plant Physiology, 143(1), pp. 461-472.

LI, X. et al. (2014). «Distinct biochemical activities and heat shock responses of two UDP-glucose sterol glucosyltransferases in cotton». Plant Science, 219-220, pp. 1-8.

MAdinA, B.R. et al. (2007). «Purification and physico-kinetic characterization of 3beta-hydroxy specific sterol glucosyltransferase from Withania somnifera (L) and its stress response». Biochimica et Biophysica Acta, 1774(3), pp. 392-402. 
MANZANo, D. et al. (2016). «Suppressing Farnesyl Diphosphate Synthase Alters Chloroplast Development and Triggers Sterol-Dependent Induction of Jasmonate- and Fe-Related Responses». Plant Physiology, 172(1), pp. 93-117.

MEN, S. et al. (2008). «Sterol-dependent endocytosis mediates post-cytokinetic acquisition of PIN2 auxin efflux carrier polarity». Nature Cell Biology, 10(2), pp. 237-244.

Moreau, R., Whitaker, B., Hicks, K. (2002). «Phytosterols, phytostanols, and their conjugates in foods: structural diversity, quantitative analysis, and health-promoting uses». Progress in Lipid Research, 41(6), pp. 457-500.

NES, W.D. (2011). «Biosynthesis of Cholesterol and Other Sterols». Chemical reviews, 111(10), pp. 64236451.

NYSTRÖM, L., SCHÄR, A., LAMPI, A.M. (2012). «Steryl glycosides and acylated steryl glycosides in plant foods reflect unique sterol patterns». European Journal of Lipid Science and Technology, 114(6), pp. 656-669.

ОнуAмA, K. et al. (2009). «Dual biosynthetic pathways to phytosterol via cycloartenol and lanosterol in Arabidopsis». Proceedings of the National Academy of Sciences, 106(3), pp. 725-730.

Promega Corporation. (2010a). Wizard Plus SV Minipreps DNA Purification System Protocol. Ed. Promega Corporation, Madison Disponible a: www.promega.es/-/media/files/ resources/protocols/technical-bulletins/0/wizard-plus-sv-minipreps-dna-purification-system-protocol.pdf. (accedit: març 2019).

Promega Corporation. (2010b). Wizard ${ }^{\circledR}$ SV Gel and PCR Clean-Up System. Ed. Promega Corporation, Madison Disponible a: www.promega.es/-/media/files/resources/ protocols/technical-bulletins/101/ wizard-sv-gel-and-pcr-clean-up-system-protocol.pdf. (accedit: març 2019).

RAMÍREZ-ESTRADA, K. et al. (2017). «Tomato UDP-Glucose Sterol Glycosyltransferases: A Family of Developmental and Stress Regulated Genes that Encode Cytosolic and Membrane-Associated Forms of the Enzyme». Frontiers in Plant Science, 8, p. 284.

RocHE, Y. et al. (2008). «Depletion of phytosterols from the plant plasma membrane provides evidence for disruption of lipid rafts». The FASEB Journal, 22(11), pp. 3980-3991.

SCHALLER, H. (2003). «The role of sterols in plant growth and development». Progress in Lipid Research, 42(3), pp. 163-175.

SCHALLER, H. (2004). «New aspects of sterol biosynthesis in growth and development of higher plants». Plant Physiology and Biochemistry, 42(6), pp. 465-476.

SchalleR, H., Bouvier-NavÉ, P., Benveniste, P. (1998). «Overexpression of an A. cDNA Encoding a Sterol-C241-Methyltransferase in Tobacco Modifies the Ratio of 24-Methyl Cholesterol to Sitosterol and Is Associated with Growth Reduction». Plant Physiology, 118(2), pp. 461-469.

Schrick, K., DeBolt, S., Bulone, V. (2012). «Deciphering the Molecular Functions of Sterols in Cellulose Biosynthesis». Frontiers in Plant Science, 3, p. 84.

SHARMA, L. et al. (2007). «Molecular cloning and characterization of one member of $3 \beta$-hydroxy sterol glucosyltransferase gene family in Withania somnifera». Archives of Biochemistry and Biophysics, 460(1), pp. 48-55.

SiNGH, G. et al. (2016). «Silencing of sterol glycosyltransferases modulates the withanolide biosynthesis and leads to compromised basal immunity of Withania somnifera». Scientific Reports, 6(1), p. 25562.

SonAWANE, P.D. et al. (2016). «Plant cholesterol biosynthetic pathway overlaps with phytosterol metabolism». Nature Plants, 3(1), p. 16205.

StUCKY, D., ARPIN, J., SCHRICK, K. (2014). «Functional diversification of two UGT80 enzymes required for steryl glucoside synthesis in Arabidopsis». Journal of Experimental Botany, 66(1), pp. 189-201.

VRanoví, E., Coman, D., Gruissem, W. (2013) «Network Analysis of the MVA and MEP Pathways for Isoprenoid Synthesis». Annual Review of Plant Biology, 64(1), pp. 665-700.

VRIET, C. et al. (2015). «Evolutionary trails of plant steroid genes». Trends in Plant Science, 20(5), pp. 301-308.

WARNECKE, D. et al. (1997). «UDP-glucose:sterol glucosyltransferase: cloning and functional expression in Escherichia coli». Plant Molecular Biology, 35(5), pp. 597-603. 
Edusfarm 11-12 (2019-2020), 223-245

ISSN: $1886-6271$

WhitAKeR, B. (1988). «Changes in the steryl lipid content and composition of tomato fruit during ripening». Phytochemistry, 27(11), pp. 3411-3416.

WhitakeR, B., GAPPER, N. (2008). «Ripening-Specific Stigmasterol Increase in Tomato Fruit Is Associated with Increased Sterol C-22 Desaturase (CYP710A11) Gene Expression». Journal of Agricultural and Food Chemistry, 56(10), pp. 3828-3835

ҮокотА, Т. (1997). «The structure, biosynthesis and function of brassinosteroids». Trends in Plant Science, 2(4), pp. 137-143. 